\title{
GABA-Modulating Phytomedicines for Anxiety:
}

\section{A Systematic Review of Preclinical and Clinical Evidence}

Karen Savage BPsych (Hons) BSci ${ }^{1,2}$

Joseph Firth BSc (Hons) ${ }^{3,4}$

Con Stough $\mathrm{PhD}^{2}$

Jerome Sarris PhD, $\mathrm{MHSc}^{1,4}$

${ }^{1}$ ARCADIA Mental Health Research Group, Professorial Unit, The Melbourne Clinic, Department of Psychiatry, The University of Melbourne

${ }^{2}$ Centre for Human Psychopharmacology, Swinburne University of Technology

3 Division of Psychology and Mental Health, University of Manchester, UK

4 NICM, School of Science and Health, Western Sydney University

Word Count: 13385 words

Conflicts of Interest: No specific conflicts noted; see general disclosures

Correspondence:

Ms Karen Savage, The University of Melbourne,

Department of Psychiatry \&The Melbourne Clinic,

This is the author manuscript accepted for publication and has undergone full peer review but has not been through the copyediting, typesetting, pagination and proofreading process, which may lead to differences between this version and the Version of Record. Please cite this article as doi: $10.1002 /$ ptr.5940

This article is protected by copyright. All rights reserved. 
2 Salisbury Street, Richmond, Victoria 3121, Australia

Email ksavage@unimelb.edu.au,

Phone 039420 9350, Fax 0394277558

Running Header: GABA-modulating Phytomedicines for Anxiety

Table of Contents

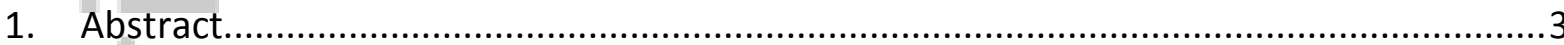

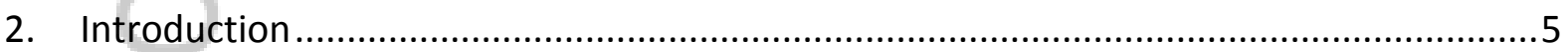

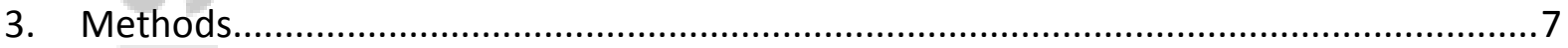

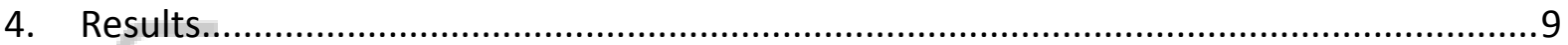

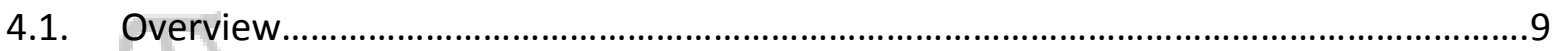

4.2. Anxiolytic phytomedicines with pre-clinical and human evidence...........................10

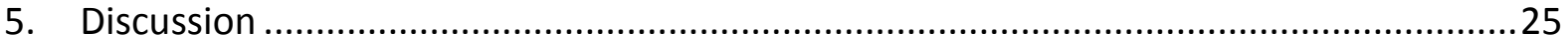

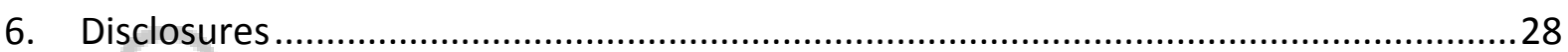

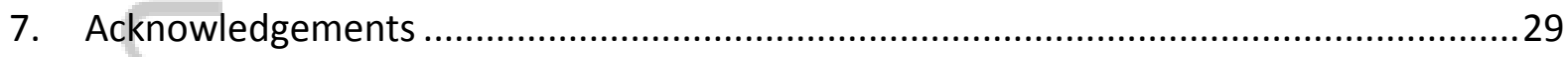

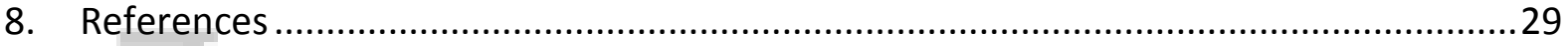

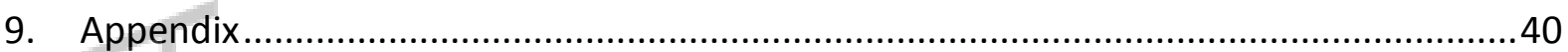

This article is protected by copyright. All rights reserved. 


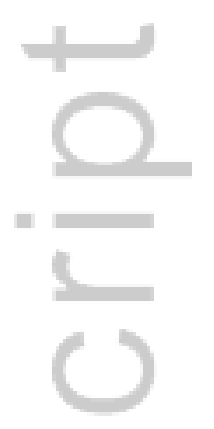

\section{Abstract}

Anxiety disorders are chronic and functionally disabling conditions with high psychological stress, characterised by cognitive symptoms of excessive worry and focus difficulties, and physiological symptoms such as muscle tension and insomnia. Gamma-aminobutyric acid (GABA) is an inhibitory neurotransmitter within the central nervous system, and is a key target of pharmacotherapies in the treatment of anxiety. While current pharmaceutical treatments are often efficacious, they may cause undesirable side-effects including cognitive decrements, and withdrawal symptoms. Plant-based 'phytomedicines' may provide novel treatment options, to act as an adjunctive or alternative to existing anxiolytic medications. As such, we conducted a systematic review to assess the current body of literature on anxiolytic phytomedicines and/or phytoconstituents. An open-ended search to $5^{\text {th }}$ July 2017 was conducted using MEDLINE (PubMed), Scopus, and Cochrane library online databases, and performed in a stepped format from pre-clinical to clinical investigations. Eligible studies must have had 1) in vitro evidence of GABA-modulating activity and 2) Animal studies using anxiety models to test an anxiolytic effect and 3) Human clinical trials. Ten phytomedicines were identified as having pre-clinical investigations showing interaction with the GABA system, in addition to human clinical trials: kava, valerian, pennywort, hops,

This article is protected by copyright. All rights reserved. 
chamomile, ginkgo biloba, passionflower, ashwagandha, skullcap, and lemon balm. Collectively, the literature reveals pre-clinical and clinical evidence for various phytomedicines modulating GABA-pathways, with comparative anxiolytic effect to the current array of pharmaceuticals, along with good safety and tolerability profiles.

Key Words: GABA, Herbal, Anxiolytic, Anxiety, Phytomedicine, Phytotherapy

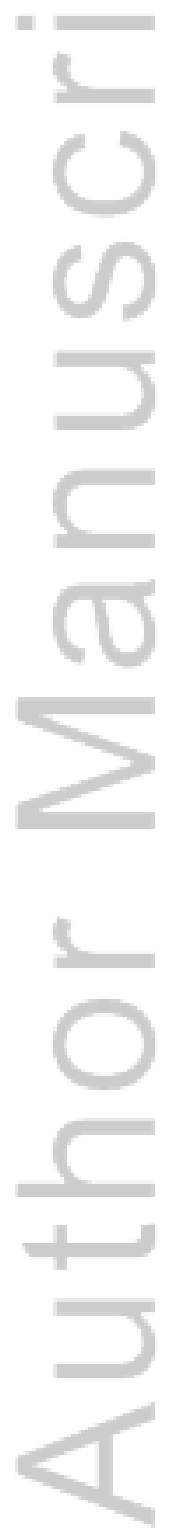

This article is protected by copyright. All rights reserved. 


\section{Introduction}

Anxiety disorders are ubiquitous and persistent conditions following a chronic course with high comorbidity (Baxter et al., 2013; Bruce et al., 2005). It is estimated over $15 \%$ of the population in developed nations will experience anxiety symptoms (which are subsumed under affective disorder diagnostic categories), yet they remain under-diagnosed and under-treated (American Psychiatric Association, 2013; Wittchen et al., 2011). The cognitive and neurophysiological dysfunction which characterises anxiety disorders has been linked to regional dysregulation of excitatory/inhibitory neurobiological pathways, notably in the limbic and pre-frontal brain regions (Etkin and Wager, 2007; Martin et al., 2010; Schienle et al., 2011).

Gamma-aminobutyric acid (GABA) is a non-standard amino acid which acts as the principal inhibitory neurotransmitter in CNS function. Up to $40 \%$ of all synapses in the CNS operate for GABA, and GABA receptors are found in every region of the human brain. Thus, GABA systems are implicit in a number of neurophysiological processes, including; motor function, pain, sleep, brain development, and importantly for the current review, anxiety. Furthermore, impairments in GABA-mediated inhibition are seen in various neurological and psychological conditions, such as movement disorders, epilepsy, schizophrenia, insomnia, and anxiety disorders (Mohler, 2001).

Pre-clinical investigations examining the role of GABA substrates in symptoms of anxiety have uncovered several pharmacological targets for treatment of these disorders. These include GABA transporters type 1 or 2 (GAT1; GAT2); GABA transaminase (GABA-T) or glutamic acid decarboxylase, and, more recently, novel allosteric binding sites on GABA-A receptors (Nuss, 2015; Puthenkalam et al., 2016; Stahl and Moore, 2013). The classes of GABA receptors identified within the human brain include GABA-A, GABA-B and GABA A-rho (formerly considered GABA-C) (Olsen and Sieghart, 2008). The GABA-A receptor exerts an inhibitory effect when activated, hyperpolarising the neuron and thus reducing the 
likelihood of an action potential occurring. Therefore, the active site of the GABA-A receptor, along with its various allosteric binding sites (which influence GABA-A receptor activity separately) and receptor subtype units, provide the main target for various anxiolytic, analgesic and sedative drugs (Ramachandran and Shekhar, 2011).

However, current pharmacotherapeutic treatments which exert anxiolytic effects primarily via the aforementioned GABA-ergic pathways (such as benzodiazepines) provide only a modest benefit for alleviating symptoms in substantial numbers of patients, and are noted for negative side effects (such as concentration and memory impairment), along with addiction/abuse issues (Baldwin et al., 2010; Hoffman and Mathew, 2008). As such, novel anxiolytic treatments which provide efficacious adjunctive or first-line treatments for anxiety, with fewer adverse consequences from long-term use, would prove highly valuable for patients with these disorders.

Various 'phytomedicines' (i.e. whole-plant or plant-extract compounds, thought to play a preventative or therapeutic role in health/disease) have been shown in both pre-clinical invitro and animal studies to possess certain pharmacodynamic properties which may confer anxiolytic effects. The pharmacodynamic effects of phytomedicines could be attributable to their constituents which may include alkaloids, terpenoids/saponins, and polyphenols, as these molecules have various hypothesized actions within the CNS including: binding with benzodiazepine (BDZ) receptor sites (e.g., GABA-alpha allosteric sites); inducing ionic channel transmission by voltage-gated blockage via alteration of membrane structures; and/or modulating enzymatic processes such as GABA transaminase (GABA-T) or glutamic acid decarboxylase (Awad et al., 2007; Johnston, 2015). Flavonoids in particular are wellknown positive modulators of GABA-A receptors (Hanrahan et al., 2011).

Whilst existing reviews have examined phytomedicines for the treatment of anxiety, the literature thus far has limitations; for instance covering affective disorders in general, or focusing on several neurotransmitter systems involved in anxiety symptomatology (Sarris, 
2007; Sarris et al., 2013a). Previous reviews have also detailed the pre-clinical evidence for GABA-ergic effects from phytomedicines, while omitting important human studies, thus reducing the clinical applicability of their findings (Awad et al., 2007; Johnston et al., 2009). Others have reviewed both pre-clinical and clinical evidence for GABA-ergic effects of phytomedicines, but focused other conditions (such as insomnia; Shi et al., 2014), or have included combination herbal formulas along with other nutritional/dietary compounds (Liu et al., 2015; Boonstra et al., 2015) making it difficult to delineate the effects of phytomedicines specifically. Thus, we conducted the first systematic review combining both pre-clinical and clinical evidence to evaluate how phytomedicines (and/or their constituents) may act within the GABA system to produce anxiolytic effects, while assessing the current level of human evidence.

\section{Methods}

An electronic search was conducted of MEDLINE (PubMed), Scopus, and Cochrane library online databases from inception to July $5^{\text {th }}, 2017$. The search was not restricted to English, should the translation via online journal or digital translation of the publication be adequate. A three-level search strategy was employed to identify phytomedicines with all of the following attributes (1) in vitro studies examining GABA-ergic activity, (2) pre-clinical animal studies of any GABA-mediated behavioural effects, and (3) human trials reporting anxiety as a primary outcome. To identify in vitro/in vivo studies, the initial primary search terms were: "PLANT" or "HERBAL" or "HERB" or "PHYTOMEDICINE" AND "GABA" or "gamma-aminobutyric acid" AND "ANXIOLYTIC" or "ANXIOLYSIS" or "STRESS" or "ANXIETY". Additionally, individual herbal medicines with both common names and Latin binomial names (where relevant), plus their known bioactive constituents, were specifically searched for. A forward search of papers included in the review was also conducted, using Web of Science and MEDLINE cited reference. A further search of grey literature was conducted to identify unpublished data.

This article is protected by copyright. All rights reserved. 
Eligible in vitro studies were those which applied preclinical methodologies towards assessing GABA-related actions of phytomedicines e.g. Xenopus laevis oocyte cell line models or ex vivo brain tissue investigations. Phytomedicines with any indicated GABA-ergic activity were eligible at this stage, including those which demonstrated direct GABA-A or GABA-B receptor binding (at either active or allosteric sites), ionic channel or cell membrane modulation, GABA transaminase or glutamic acid decarboxylase inhibition, and/or phytomedicines examined in interactions with known GABA receptor antagonists, such as flumazenil.

We then sought for pre-clinical studies which used established animal models of anxiety, along with related behavioural paradigms (e.g. grooming behaviour, maze models, or light/dark exposure models), to examine in vivo anxiolytic effects of phytomedicines found to have evidence of GABA-ergic activity revealed in stage 1.

In the final stage of the search, to identify human trials of relevant phytomedicines, we conducted a further search using the terms: "Anxiety" OR "Generalised Anxiety Disorder" OR "Anxiety Disorder", in addition to anxiety disorders as defined by Diagnostic and Statistical Manual of Mental Disorders, Edition 5 (DSM-V; American Psychiatric American Psychiatric Association, 2013) e.g. panic /agoraphobia, social phobia, and post-traumatic stress disorder, along with 'AND' terms for a list of the phytomedicines (using both common names and Latin binomial names) which had been identified by the earlier search stages to have GABA-mediated anxiolytic effects in in vitro/in vivo studies. Human trials with any design were eligible (including randomized, open-label, or single arm studies), provided that the total sample size was 10 or more participants (case studies were also excluded). In cases where a recent (i.e. since 2010) review (and meta-analysis of human trials) had already been conducted on the three levels of evidence for a specific phytomedicine included here (i.e. Piper methysticum, Withania somnifera), the review was used preferentially over detailing all the individual studies (although updated with a subsequent relevant research).

This article is protected by copyright. All rights reserved. 
'Traditional' use of selected phytomedicines was cross-referenced with British Herbal Medicine Association Pharmacopoeia (British Herbal Medicine British Herbal Medicine Association, 1996) and Martindale Complete Drug Reference (Brayfield, 2014). The dosing regimen of phytomedicine products consisted mainly of a single dose unless otherwise specified as multiple doses.

Insert Figure 1 about here

\section{Results}

\subsection{Overview}

The literature search found 1328 articles relevant to initial search parameters, for which 1212 were excluded following a check against criteria for pre-clinical or clinical phytomedicine studies. A total of 10 identified phytomedicines (key constituents or whole plant preparations) met inclusion criteria and were reviewed. Three phytomedicines found to be lacking one of the three areas of evidence (preclinical tissue and animal, and clinical human studies) are later discussed in brief in the Discussion section. Refer to Figure 1 for the selection processes flowchart.

Of the animal models employed, most being rodent type, the elevated-plus maze (EPM) was most typical; consisting of open and closed trajectories along with a timed measure of arm entry exploration, which reflect animal anxiety levels (Lister, 1987; Walf and Frye, 2007). Other paradigms included timing durations spent in light/dark and open field environments, and measuring grooming, conflict avoidance and social behaviours. Anxiety measures used in the clinical studies were: Hamilton Anxiety Scale (HAMA; Hamilton, 1959); Spielberger State Trait Anxiety Inventory (STAI; Spielberger et al., 1983); Erlangen Anxiety, Tension and

This article is protected by copyright. All rights reserved. 
Aggression Scale (EAAS; Galster and Spörl, 1979); the Befindlichkeitsskala Well-being Self Rating Scale (Bf-S; von Zerssen, 1976), Anxiety Sensitivity Index (ASI; Reiss et al., 1986), and Clinical Global Impressions scale (CGI; Guy, 1976). Various biomarkers were also used as proxy measures of physiological anxiety, including: hormones (adrenaline, cortisol, adrenocorticotropic hormone, noradrenaline levels) as well as neurophysiological data - skin conductance; heart rate; and blood pressure.

Insert Table 1 about here

\subsection{Anxiolytic phytomedicines with pre-clinical and human evidence}

\section{Centella asiatica (Gotu cola/kola, pennywort)}

Centella asiatica is a native Asian herbaceous species used commonly as a whole plant extract in Indian Ayurvedic and Chinese Traditional Medicine (Diwan et al., 1991; Gohil et al., 2010). Modern indications are for dermatotic, antimicrobial, nociceptive, cognitionenhancing, anxiolytic and anti-depressive purposes (Anukunwithaya et al., 2016; Lokanathan et al., 2016). The chief constituents are triterpenoid glycogens (saponins), sterols, flavonoids, tannins and stearic acids. Investigations of constituents have chiefly involved the saponins brahmoside and brahminoside, and the asiatic and ursolic acids (Brinkhaus et al., 2000; James and Dubery, 2009).

GABA-ergic effects of Centella asiatica (and constituents) were revealed in studies analysing GABA-transaminase (GABA-T) and glutamic acid decarboxylase (GAD) activity. One study (Awad et al., 2007) reported C. asiatica significantly increased glutamic acid decarboxylase activity in vitro by more than $50 \%(p<0.001)$ in Male Sprague-Dawley rat brain assays. In a further in vitro study of GABA-A subtype receptor modulation (Hamid et al., 2016), the asiatic acid constituent was found to be negative modulator of GABA-induced currents for $\alpha 1 \beta 2 \gamma 2 \mathrm{~L}, \alpha 2 \beta 2 \gamma 2 \mathrm{~L}$ and $\alpha 5 \beta 3 \gamma 2 \mathrm{~L}$ receptors in Xenopus oocyte tissue. Further, in an ex vivo

This article is protected by copyright. All rights reserved. 
study using Charles-Foster rats (Chatterjee et al., 1992), C.asiatica extract was found to increase whole brain levels of GABA.

In rodent models, the constituent triterpenoid extracts of Centella asiatica (madecassoside and asiaticoside) have been shown to be as effective as diazepam for alleviating behavioural symptoms of anxiety in chronic stress settings of EPM, open-field and dark-light box tests, as well as acute stress models (i.e. immobilisation stress test) in adult male Imprinting Control Region (ICR) mice (Wanasuntronwong et al., 2012). Another study (Wijeweera et al., 2006) reported significant anxiolytic effects in EPM tests from both methanol and ethyl acetate extracts of $C$. asiatica, along with the isolated asiaticoside constituent in male SpragueDawley rats. A final animal study (Ceremuga et al., 2015) investigated the anxiolytic effects of an injected peritoneally asiatic acid extract in four male Sprague-Dawley rat comparison groups. Asiatic acid significantly increased EPM measures of open-arm latency, and mobility speed and latency (all indicating reduced anxiety). Further, the investigation reported that administration of GABA receptor antagonist flumazenil attenuated the anxiolytic effects of asiatic acid, thus indicating that the anxiolytic effects of asiatic acid are due to GABA-ergic benzodiazepine receptor activity.

A human study examined the effects of an acute dose of C.asiatica extract (12 grams) on measures of stress and anxiety, including acoustic startle response (ASR), against a placebo comparator in 40 healthy adults (Bradwejn et al., 2000). The results showed significant attenuation of acoustic startle response in the treatment group. Another clinical investigation conducted an open label study of $500 \mathrm{mg}$ of the phytomedicine twice daily for two months in a sample of 33 patients with GAD (Jana et al., 2010). The study found significant improvements in anxiety following 60 days of treatment $(p<0.01)$ on the HAM-A scale, along with significant reductions in secondary measures of stress and depression.

\section{Humulus lupulus (Hops)}

This article is protected by copyright. All rights reserved. 
The flowering cones of Humulus lupulus (Cannabaceae) have sedative/hypnotic, antibacterial, anti-inflammatory traditional indications, however the plant is chiefly cultivated worldwide for alcoholic beverages derived from malted grain, namely 'beer' (Katsiotis et al., 1989). Modern medicinal indications exist for anxiety and insomnia (Blumenthal, 2009; Martin et al., 2002), mostly associated with principal terpenoid and flavonoid alpha and beta acid constituents, such as humulene and myrcene.

In vitro studies of myrcenol (found in the $H$. lupulus plant) have demonstrated GABA-A receptor response potentiation in Xenopus oocytes (Aoshima et al., 2006). Additionally, a combination study (Muller et al., 2002) investigated how hops extract and Valeriana officinalis influenced binding at adenosine receptors within rat cortical and striatum membranes, and found that although $V$. officinalis in combination with hops affected this process, hops alone did not - indicating that the mechanism through which hops produces sedative effects may be through GABA receptor activity instead. Pre-clinical research further supported GABA-ergic effects of $H$. lupulus (extract $0.11-0.65 \mathrm{mg} / \mathrm{mL}$ ) in male SpragueDawley rat brains (Awad et al., 2007), through inhibiting glutamic acid decarboxylase activity.

Animal models examining effects on sedation and anxiety have also been conducted: one investigation (Franco et al., 2012a) found that $H$. lupulus extract reduced nocturnal activity in an avian model (common quail) and preserved an activity/rest cycle which matches regular circadian rhythms. Similarly, an investigation using female NMRI mice found that $H$. lupulus extract reduced locomotor activity and reduced body temperature consistent with sedating properties (Schiller et al., 2006). However, a preclinical study of $H$. lupulus specific constituent xanthohumol reported no evidence of anxiolysis via GABA-ergic mechanisms of this particular component using male Sprague-Dawley rats, suggesting effects occur by a different constituent, or pathway (Ceremuga et al., 2013).

This article is protected by copyright. All rights reserved. 
In human studies, one investigation (Franco et al., 2012b) measured sleep quality, circadian rhythms, and anxiety/stress levels of 17 'work stressed' shift workers for a regular seven nights (control period) and then following 14 days of nightly ingestion of a $330 \mathrm{ml}$ alcoholfree beer. The study found significant reductions in state anxiety vs. the control condition. Aside from this study, the anxiolytic effects of $H$. lupulus have not been widely examined, with the majority of studies focusing on sedating and hypnotic properties instead. As such, the anxiolytic potential of $H$. lupulus in anxiety symptom alleviation is yet to be substantiated through clinical research, despite clear indications of GABA-ergic mechanisms from pre-clinical research.

\section{Ginkgo biloba (Maiden hair)}

The ginkgo tree (Ginkgo biloba) is one of the oldest angiosperm species, with the nuts and leaves being used for a range of therapeutic effects (Shizhen, 1990). Active constituents are mainly flavonoids quercetin and catechin, unique terpenoids ginkgolides and bilobalides, and proanthocyanidins (van Beek and Montoro, 2009). Tissue studies of human endothelial cell lines indicate that constituents from the leaves as standardised extract have potent neuro-protective and anti-apoptotic properties, as well as vasculatory benefits via nitric oxide (NO) enhancement (Koltermann et al., 2007). Modulations to cholinergic and monoaminergic pathways have also been evidenced in female Wistar rats and NMRI mice models ex vivo, thereby offering benefit for cognition and mood (Fehske et al., 2009).

Pre-clinical studies were located investigating GABA-ergic mechanisms of action, however to date the findings are not entirely clear. The ginkgolides A, B, C and bilobalide were reported to operate as antagonists at recombinant $\alpha 1 \beta 2$ 2L GABA-A receptors expressed in Xenopus oocytes in tissue investigations, and to exact mixed antagonist action involving similar models with recombinant human $\rho 1$ GABA-C receptors ( Huang et al., 2003; 2004; 2012). Additionally, an increase of GABA in hippocampal, cortical and striatum tissue in male ddY strain mice assayed ex vivo was reported in the presence of bicuculline and pictrotoxin, 
thought to occur via potentiating glutamic acid decarboxylase and thus operating as an anticonvulsant (Sasaki et al., 1999; 2000). A tissue study also reported that both the ginkgolides and bilobalide selectively inhibit GABA-A receptors to the same extent as the pictrotoxin comparator in Sprague-Dawley rat brain tissue ex vivo when exposed to ginkgolides A, B, C, and J and bilobalide (Ivic et al., 2003). The study discussed structural similarities of G.biloba constituents to the GABA-A receptor antagonist, picrotoxinin. One investigation examined further the GABA-A mechanisms of action for bilobalide in rat hippocampal tissue and reported a blocking of GABA-induced chloride uptake in these cells at low potency. In turn, GABA was found to partially antagonize bilobalide's inhibitory actions (Kiewert et al., 2007). One recent study reported that both bilobalide and ginkgolide $B$ selective inhibited structurally varied GABA-A positive modulator agent actions by when tested in Xenopus oocytes ( $\mathrm{Ng}$ et al., 2017).

In anxiety rodent models, ginkgolides A, B, C, and bilobalide (individually and combined) were tested using the EPM paradigm with mice (Kuribara et al., 2003). The study found significant dose-dependent relationships between ginkgolide $A$ with reductions in anxiety (i.e. increased open arm time). However, these beneficial effects were not blocked by flumazenil; suggesting that these constituents exert anxiolytic effects through alternate routes to GABA receptors. A further pre-clinical study of bilobalide treatment found increased locomotor activity in open field and EPM tests, and reduced latency in Morris water maze, using male Kunming mice, with glucocorticoid receptor modulation as a hypothesized mechanism of action (Ma et al., 2012). One human study testing G.biloba extract at doses of either $480 \mathrm{mg}, 240 \mathrm{mg}$ or placebo in 170 patients with GAD reported significant improvements on HAM-A scale in the treatment groups after 4 weeks, with greatest effects in the high-dose condition (Woelk et al., 2007).

\section{Matricaria recutita/Matricaria chamomilla (Chamomile, German chamomile)}


Matricaria recutita, an Asteraceae (daisy) family flowering plant, is plentiful throughout Eurasia, and has been utilised for millennia, chiefly as tea, for calming/sedative effects (McKay and Blumberg, 2006). The bioactive constituents include sesquiterpenes, coumarins (herniarin, umberlliferone, amongst others), flavonoids including apigenin, luteolin and rutin, and phenylpropanoids (chlorogenic and caffeic acids)(Srivastava et al., 2010).

Tissue studies report that certain M.recutita constituents modulate the function of GABA receptors via ligand effects on the central BDZ site, with a reduction of GABA-activated $\mathrm{Cl}$ currents, with evidence of action in other (possibly monoamine) pathways in SpragueDawley rat brain assays (Avallone et al., 1996; 2000). Principally, the flavonoid apigenin has been investigated - present also in other plant species - with anxiolytic effects as an inverse benzodiazepine agonist (Johnston, 2015; Viola et al., 1995), potentially biphasic action via receptor subunits similar to benzodiazepines (Campbell et al, 2004; Hanrahan et al, 2011) as the activity on BDZ receptors is somewhat equivocal (aforementioned Avallone et al., 2000). Animal models have supported this, reporting sedative and anxiolytic effects. For instance one study (Shinomiya et al., 2005) found administration of the extract improved sleep latency in male Wistar rats and that these effects were attenuated from co-administration of flumazenil, thus implicating GABA-ergic BDZ receptor modulation as the likely mechanism when measured ex vivo. Another study further reported significant reductions in anxiety behaviours in male Balb/c mice via in various testing paradigms, including open field, EPM and social interaction paradigms (Can et al., 2012).

In humans, a double blind RCT with 57 GAD patients showed significantly greater reductions in anxiety (HAM-A) among those undergoing M. recutita treatment $(220 \mathrm{mg}$, one to four times daily) than those in the control condition, after 8 weeks (Amsterdam et al., 2009). A post-hoc analysis of the same sample found that $M$. recutita may also reduce co-morbid depression (HAM-D) in anxious patients (Amsterdam et al., 2012).

This article is protected by copyright. All rights reserved. 
Three further human studies reported short- and long-term (i.e. 8 and 38-weeks) effects of treatment for anxiety with 1500mg (500mg capsule 3 times daily) in a sample of 179 patients with GAD. At 8 weeks, $58 \%$ of patients met the criteria for 'clinical response' $M$. recutita treatment, with significant reductions in mean anxiety (GAD-7) across the entire sample (Keefe et al., 2016). For the long-term study, those who were 'responders' were randomly assigned to continued active or placebo treatment for a further 26 weeks. GAD relapse rates were $25.5 \%$ in the placebo group, and only $15.2 \%$ in the continued treatment group (Mao et al., 2016). Although the difference in relapse rates did not reach statistical significance, GAD-7 ratings were significantly improved in the continuation vs. placebo conditions. Another clinical investigation in 34 patients with DSM-IV primary insomnia found significant improvements over placebo from 28 days of $270 \mathrm{mg}$ M. recutita twice-daily to ratings of fatigue, sleep quality and latency, but with no significantly relevant changes in symptoms of anxiety (Zick et al., 2011).

\section{Melissa officinalis (Lemon Balm)}

Lemon balm is reported in Theophastrus' Historia Plantarum (350 BC - c. 287 BC), thus holding longstanding use for millennia. It is native to Eurasia as a member of the Lamiaceae (mint) family, with a number of phytochemicals including phenolic acids, terpenes, rosmarinic and caffeic acids, eugenol acetate, and tannins. Indications are for anti-bacterial, anti-stress, hypnotic, and gastrointestinal symptom benefit (Shakeri et al., 2016; Ulbricht et al., 2005).

In vitro studies have indicated various GABA substrate activity for M. officinalis constituents such as elevation of GABA levels, owing to inhibition of GABA-T, as observed in male Sprague-Dawley rat brain homogenized tissue samples (Awad et al., 2007; Awad et al., 2009). An aqueous extract of M.officinalis (rosmarinic acid) inhibited GABA-T activity (IC50 = $0.35 \mathrm{mg} / \mathrm{mL}$ ) in the former study (Awad et al., 2007), and replicated in the latter study (Awad et al., 2009). An additional investigation of the triterpenoids, ursolic oleanolic acids 
found that these constituents also increase GABA-A benzodiazepine receptor affinity in rat brain tissue (Salah and Jager, 2005). A neurotropic tissue study (Yoo et al., 2011) reported decreased GABA-T levels in the dentate gyrus of C57BL/6 J mice, along with an increase in total GABA levels, following extract $50 / 200 \mathrm{mg} / \mathrm{kg}$ daily for three weeks. Finally, in radioligand/electrophysiological studies using male Wistar rat cortical cultures in vitro, M.officinalis extract and selected constituents have shown trans-ocimene inhibited [35S] (TBPS) binding (set radio ligand) at GABA-A receptor level, in a dose-dependent fashion (Mahita et al., 2014), building upon previous similar findings in pre-clinical investigations (Abuhamdah et al., 2008; Huang et al., 2008).

Rodent model studies have reported a dose-dependent response on the EPM with $\mathrm{C} 57 \mathrm{BI} / 6$ Jico mice using the extract 'Cyracos' (Naturex, Melissa officinalis L. Extract): with principal constituents rosmarinic acid and triterpenoids oleanolic and ursolic acids (Ibarra et al., 2010). Similarly, a second study (Taiwo et al., 2012) used EPM and open field measures to show significant anxiolytic effects of M.officinalis extract in male and female Wistar rats, which matched those of the diazepam comparator.

In contrast, one pre-clinical study (Raines et al., 2009) reported the constituent luteolin confers additive or synergist effects in the presence of a GABA-A agonist but not alone; reporting no differences in anxiety behaviours using an EPM model with male SpragueDawley rats between the constituent and a flumazenil group, both administered with a GABA-A benzodiazepine agonist, suggesting that anxiolysis also occurs via different mechanisms.

In human investigations, an open-label study (Cases et al., 2011) in a self-reported 'stressed' sample, showed a $15-42 \%$ reduction in insomnia and mild-to-moderate anxiety symptoms over 15 days from 600mg per-day of Cyracos (standardised to $7 \%$ rosmarinic acid and greater than $15 \%$ hydroxycinnamic acid derivatives). In a healthy sample study (Kennedy et al, 2002) a laboratory stress-induction paradigm showed improvements in mood and 
attention from M.officinalis extract. Several similar studies with other laboratory-based paradigms have also reported improvements from M.officinalis, which are consistent with anxiolytic-like effects (Kennedy et al., 2003; 2004; Scholey et al., 2014) . Finally, a doubleblind RCT in 100 young females (Akbarzadeh et al., 2015) reported efficacy of 1200mg of M.officinalis extract daily over 3 months for reducing stress and tension associated with Premenstrual Dysphoric Disorder.

\section{Passiflora incarnata (Passion flower)}

Passiflora incarnata is native to the Americas having been utilised for millennia for conditions of nervousness, anxiety and sleep issues (Krenn, 2002; Meier, 1995; Miroddi et al., 2013). The chief identified constituents include alkaloids such as chrysin, flavonoids such as schaftoside, isoschaftoside and swertisina, and phenolic compounds (Wohlmuth et al., 2010). GABA-ergic modulation could feasibly occur through number of processes, including affinity with GABA-A and GABA-B receptor subtypes and GABA reuptake inhibition, and also via positive allosteric modulation of the GABA-A receptor complex through benzodiazepine sites (Appel et al., 2011; Nassiri-Asl et al., 2008).

A combined in vitro/in vivo study (Elsas et al., 2010) used a pentelenetrazol (PTZ)-induced seizure procedure in a CF-1 mice model to examine effects of $P$. incarnata extract, which was reported to induce direct GABA-A currents in CA1 hippocampal pyramidal neurons. Another combined in vivo/in vitro study (Grundmann et al., 2008) utilised a P.incarnata extract (as homo-orientin, orientin, vitexin, and isovitexin) in male BL6/C57

EPM model to show behavioural anxiolytic effects matching those of diazepam from moderate-strength doses. Furthermore, the findings that flumazenil acted as an antagonist against P.incarnata demonstrates GABA-mediated pathways for the anxiolytic effects. A related study (Grundmann et al., 2009) examined effects in a similar rodent EPM model using three strengths of P.incarnata with diazepam comparator, finding a U-shape trend dose-response efficacy, in favour of the middle dose $(375 \mathrm{mg} / \mathrm{kg})$.

This article is protected by copyright. All rights reserved. 
Several in vivo studies investigated both dose and constituent optimisation; the first (Dhawan et al., 2001) used a Swiss mice (male and female) EPM model to delineate potency of different plant components, reinforcing use of the flower for maximal anxiolytic effects. A second study (Sampath et al., 2011) used differential EPM performances in male C57BL/6J mice to ascertain optimal fractionalisation methods; and a third (Wolfman et al., 1994) used anxiolytic and sedative paradigms (EPM, hole board and horizontal wire) in male CF1 mice to examine the constituent chrysin (5,7-dihydroxyflavone) with a diazepam comparator, reporting no significant differences in anxiolytic effect, but an increase to head-dipping and myo-relaxant properties via horizontal wire test in the BDZ group. Finally, a recent study (Aman et al., 2016), observed anxiolytic and sedative effects of P.incarnata in staircase and open field tests, with BALB/c mice and female Sprague Dawley rats, which were antagonised by pentylenetetrazole, indicating the behavioural effects of P.incarnata occurred through GABA-ergic mechanisms, however precise mechanisms were again unclear.

Seven studies involving human populations were found; four examined effects on preoperative anxiety in RCTs (Aslanargun et al., 2012; Dantas et al., 2017; Kaviani et al., 2013; Movafegh et al., 2008), all reporting significant benefits from P.incarnata treatment in comparison to placebo conditions and/or non-inferiority to BDZ comparators. Most recently, this effect was observed in a double-blind RCT of 40 dental surgery patients (Dantas et al., 2017), showing $260 \mathrm{mg}$ of P.incarnata orally administered 30 minutes before dental surgery reduced subjective anxiety along with physiological indicators (i.e. blood pressure, heart rate) to the same extent as midazolam, with fewer cognitively-impairing side effects.

The benzodiazepine-like efficacy has also been observed for psychiatric disorders. First, a double-blind RCT in 36 patients with GAD (Akhondzadeh et al., 2001) found no significant difference between P.incarnata extract (administered as liquid drops) to oxazepam comparator after 4-weeks. Second, another investigation (Mori et al., 1993) found no 
difference between extract ('Passiflamin' 90mg) and mexazolam comparator groups for anxiety measures in patients with 'neurosis'.

\section{Piper methysticum (Kava)}

Kava (Piper methysticum) is a plant native to the South Pacific, where the roots have been used in traditional medicine for a range of conditions via its anxiolytic, nootropic and neuroprotective, nociceptive and dysphoric actions (Singh, 1992; Tzeng and Lee, 2015). The chief bioactive constituents are the six lipophilic kavalactones, of which kawain and dihydrokawain are evidenced to exert the strongest anxiolytic activity. Mechanisms evidenced in pre-clinical models primarily involve modulation of GABA receptors, and although the exact mechanisms are not clear, these models suggest several avenues beyond an allosteric mode of action in the GABA substrate, such as rapid upregulation of GABA-A receptor function, blockade of voltage-gated sodium ion channels, enhanced ligand binding across GABA-A receptor subtypes, and reduced excitatory neurotransmitter release via blockade of calcium ion channels (Magura et al., 1997; Gleitz et al., 1995; Jussofie et al., 1994; He et al., 1997; Mathews et al., 2005). Table 1 details these studies further. Abundant animal anxiety model investigations exist (e.g., Garrett et al., 2003; Rex et al., 2002), reporting anxiolytic effects (such as reduced entry latencies and increased time in unfamiliar environments) in rodent EPM and other paradigms.

A number of clinical reviews published have systematically examined the mechanisms and efficacy of kava in the clinical treatment of anxiety, including an early Cochrane review on (Pittler and Ernst, 2003), along with a more recent review of preclinical and clinical investigations (Sarris et al., 2013a; 2013b). From human clinical studies these reviews indicate P.methysticum is superior to placebo in the treatment of anxiety symptoms. For instance, a pooled effect size calculated for HAM-A scores across 6 RCTs of Kava found large, significant reductions in anxiety in favour of the extract (Cohen's $d=1.1$ ) (Sarris et al., 2011). A subsequent RCT has also confirmed these findings (Sarris et al., 2013c) observing

This article is protected by copyright. All rights reserved. 
moderate effects on reducing anxiety reported with the HAM-A in a GAD sample $(n=75)$ treated with either kava (120/240 mg kavalactones), compared to placebo, for 6 weeks.

Through combining human evidence alongside pre-clinical (in vitro and in vivo) studies, reviews have also found strong indication that the anxiolytic effects of kava are due (at least in part) to the extract's multiple GABA-ergic actions (Sarris et al., 2013a; Sarris et al., 2013d Again, the conclusions drawn from these earlier reviews have been supported by recent studies, whereby GABA-ergic mechanisms are investigated in more detail; in a recent tissue study examining actions of a specific P.methysticum phytoconstituent 'kavain' on expressed Xenopus oocytes (Chua et al., 2016) found that positive allosteric modulation occurred across all GABA-A receptor subtypes examined ( $\alpha 1 \beta 2, \beta 2 \gamma 2 \mathrm{~L}, \alpha x \beta 2 \gamma 2 \mathrm{~L}(\mathrm{x}=1,2,3$ and 5), $\alpha 1 \beta x y 2 L(x=1,2$ and 3 ) and $\alpha 4 \beta 2 \delta)$, and where this action was not affected by administration of flumazenil, implicating sites other than BDZ receptors.

\section{Scutellaria lateriflora (Scullcap, Blue Skullcap)}

Scutellaria lateriflora is native to America and Europe with use in Native American practice and Western medicine for anti-anxiety, relaxant and anti-spasmodic effects (Mills and Bone, 2000). Identified chief bioactive constituents include a number of flavonoids; scutelaterin $A$, baicalin, bacalein, apigenin, oroxylin A, and wogonin (Li et al., 2012; Zhang et al., 2009). Preclinical studies have found several constituents of S.lateriflora have GABA-ergic properties, including baicalin and baicalein, wogonin and apigenin, as these constituents act at the benzodiazepine site of GABA-A receptor via positive allosteric modulation (Awad et al., 2003; Wang et al., 2008; Xu et al., 2006). Animal studies have also shown behavioural changes which reflect these GABA-mediated anxiolytic properties. For instance, one investigation (Awad et al., 2003) observed S.lateriflora extract significantly increased open field entries, head dips and time spent in open arms in an EPM paradigm with male SpragueDawley rats.

This article is protected by copyright. All rights reserved. 
Two human studies using S.lateriflora extract were found, both in non-clinical samples. One double-blind crossover study ( $n=43$; Brock et al., 2014) reported significantly greater mood improvement after two weeks from 350mg extract (three times per day) than placebo comparator. Although there was no difference in anxiety outcomes between groups, this was ascribed to a 'floor effect' - as these healthy volunteers were mostly non-anxious at baseline. Nonetheless, an earlier briefly detailed pilot investigation reported clinically significant reductions in anxiety and stress from various strengths of S.lateriflora in 19 healthy volunteers (Wolfson and Hoffmann, 2003).

\section{Valeriana spp. (Valerian)}

Valerian is a perennial plant native to mainly Europe, with the root extract utilised medicinally for millennia as a sedative and anxiolytic. The bioactive constituents include alkaloids, flavonones and terpenes (specifically the sequiterpene valerenic acid) (Houghton, 1988). The results of pre-clinical studies have indicated that Valerian spp. modulates the GABA-ergic system through potentiation of GABA release and inhibition of re-uptake or degradation, via inhibited GABA transaminase (GABA-T) activity in brain tissue from male Sprague-Dawley rats, female Swiss-Webster mice, and male Wistar rats, respectively (Awad et al., 2007; Ortiz et al., 1999; Santos et al., 1994).

Valerenic acid as the principle constituent was identified as a subunit specific allosteric modulator of GABA-A receptors, specifically acting as an agonist at $\beta 2 / 3$ subunits in male RjHan:WI rat cortical tissues and in Xenopus oocytes tissue investigations, likely to interact with the loreclezole binding pocket (Becker et al., 2014; Khom et al., 2007; 2016; Trauner et al., 2008)

The in vitro findings are reflected through in vivo studies; with animal models demonstrating anxiolytic properties of valerian extracts with female NMRI mice and male Sprague-Dawley rats on the EPM (and also anti-depressant effects via forced swim test model) (Hattesohl et al., 2008), that it is equitable to benzodiazepine comparators in female Hooded Wistar rats (Murphy et al., 2010), while also providing a strong indication that these behavioural effects 
are due to valerenic acid and valerenol constituents modulating GABA-A receptors, specifically $\beta 3$ subtypes from one combined in vitro and in vivo study involving human embryonic kidney cell lines and in $\beta 3$ point-mutated mice and the EPM and light-dark choice behavioural tests, using valerenic acid and valerenol extracts (Benke et al., 2009).

In human studies, one investigation (Kohnen and Oswald, 1988) showed that valerian extract reduced subjective feelings of anxiety among healthy adults in a stress-inducing scenario, and that these effects occurred independently of the beta-blocker propranolol. Additionally, another study (Ahmadi et al., 2017), in a double-blind RCT with 51 HIV-positive patients, found that $530 \mathrm{mg}$ of valerian extract daily for 4 weeks significantly reduced the anxiety which commonly occurs as a neuropsychiatric side-effect of antiretroviral therapy.

In affective disorder samples, a placebo-controlled, 8 week clinical study of V.officinalis root extract (765 mgs per day) among 31 adults with OCD (DSM-IV diagnosed) found the extract significantly reduced symptoms of the disorder (Pakseresht et al., 2011). Another RCT compared a mixture of isolated valepotriates (from valerian), diazepam and placebo over four weeks in 36 patients with GAD (Andreatini et al., 2002). Although there were no significant differences between groups on total symptom scores, valerian appeared to be relatively more effect for psychic symptoms of anxiety (according to HAMA subscales), whereas diazepam performed better for STAI trait anxiety.

Two further studies examined the anxiolytic and sedating effects in a safety context; the first investigated driving performance and sedating effects with placebo comparator, finding no detrimental effects from valerian (Thomas et al., 2016). The second in a similar design $(n=10)$, assessed subjective sedation and psychomotor/cognitive performance effects of V.officinalis extract, diazepam and placebo control; finding decrements only occurred from the benzodiazepine comparator (Gutierrez et al., 2004). 


\section{Withania somnifera (Ashwagandha, Indian ginseng, winter cherry)}

Withania somnifera is an alkaloid-rich plant from the nightshade family, traditionally utilised in Indian Ayurvedic medicine for the adaptogenic or 'rasayana' properties of the root extract (Mishra et al., 2000). The constituents include glycosides (withanolides), alkaloids (withanine, ashwagandhine, ashwaganidhine, and somniferine) and steroidal triterpenoid lactones, which are related to the ginsenosides, hence the common name 'Indian ginseng'. Tissue studies investigating GABA-ergic actions of withaferin, withanolides-A, and methanol extract of W.somnifera have found these constituents are GABA-A and GABA- $\rho 1$ receptor agonists Xenopus cell lines that also included transplanted Sprague-Dawley rat brain GABA channels (Candelario et al., 2015; Yin et al., 2013). In rodent models using EPM, social interaction and feeding latency/unfamiliar environment paradigms, withanolides have been shown to have equivalent anxiolytic effects to benzodiazepine comparators (lorazepam) in male Charles-Foster rats (Bhattacharya et al., 2000; Kaur et al., 2016).

In human studies, a recent systematic review (Pratte et al., 2014) captured all previous studies of W.somnifera with anxiety/stress outcomes. This identified five human RCTs with a total of 400 participants (range=39 to 130). All five trials reported at least one significant benefit of $W$.somnifera in comparison to control conditions for anxiety and/or stress related outcomes. Doses ranged from $125 \mathrm{mg}-1200 \mathrm{mg}$ per day, over 6 to 16 weeks. Since this review, one further eligible study has been conducted; a double-blind RCT in 52 people with chronic stress, comparing 600mg of W.somnifera extract per-day to placebo capsules over 8 weeks (Choudhary et al., 2017). The study showed significantly greater reductions in stress outcomes from the extract, corresponding with significant decreases in salivary cortisol (a stress/anxiety biomarker).

This article is protected by copyright. All rights reserved. 


\section{Discussion}

An increasing number of phytomedicines and their bioactive constituents with evidenced GABA mechanisms have been studied in the treatment of generalised anxiety symptoms in addition to clinically-diagnosed anxiety disorders. Despite the increased use of phytomedicines, with up to $80 \%$ of the world's population using some form of herbal medicine (World Health Organization, 2003), most still lack rigorous investigations of clinical efficacy. This is a common observation from previous reviews of CNS mechanisms of phytomedicines for affective disorders (including anxiety) (Ernst, 2006; Sarris, 2007; Lakhan and Vieira, 2010; Liu et al., 2015). In particular, there are a paucity of clinical investigations for phytomedicine use in the treatment of GAD, especially given the epidemiological prevalence of this particular disorder (Australian Bureau of Statistics, 2007; Wittchen et al., 2011).

In the current review, in vitro and in vivo animal studies both revealed GABA-mediated anxiolytic effects from various phytomedicines (as whole extracts and/or isolated constituents). This was demonstrated via a range of mechanisms, which include direct and allosteric interaction with GABA receptor, up-regulation of relevant agonists, and/or interactions with antagonist drugs such as flumazenil or pentylenetetrazole. However, there is also evidence that some of the phytomedicine constituents included in this review modulate ionotropic GABA receptors independently or only partially from flumazenilsensitive benzodiazepine sites such as that occurring with diazepam (c.f. Johnston, 2005). For example, chrysin is known to be a partial agonist at the central BDZ binding site, but apigenin competitively binds to GABA-A BDZ site, also appears to act on both flumazenilsensitive and -insensitive components, and the effects of Kavain are not blocked by flumazenil, which suggest a different site of action (c.f. Johnston et al., 2006; Hanrahan et al., 2011). In most cases, the precise sites of GABA-A receptor action are still to be ascertained, because subtype specificity for phytoconstituents has not been fully 
investigated in tissue and animal models.

Despite the need for pre-clinical research of GABA pathway mechanisms and subtypeselectivity behaviours, the next level of pre-clinical involving rodent models have demonstrated these GABA system effects result in reduced anxiety/stress related behaviours in established paradigms such as the EPM, light/dark box, and open fields. However, for some of these plant medicines there is currently a deficit of studies examining their anxiolytic potential for clinically-diagnosed anxiety disorders.

Of the phytomedicines reviewed, $P$. methysticum has the largest evidence base for use in the anxiety disorders, with tripartite level of support from in vitro, in vivo, and human clinical studies. The number of positive findings from human studies of P.methysticum within randomised, well-controlled trials also supports its use as a treatment for various anxiety disorders and associated symptoms, demonstrating broad potential clinical utility (Sarris et al., 2011; 2013b). Thus, P. methysticum remains the hallmark anxiolytic phytomedicine (minor concerns over liver toxicity notwithstanding). It is the most strongly evidenced for generalised anxiety, with clinical investigations now examining GABA metabolite changes via neuroimaging, and whether individual gene differences in GABA pathway polymorphisms influence treatment response (Savage et al., 2015).

V.officinalis, C.asiatica, M.recutita, G.biloba, P.incarnata and W.somnifera offer the next most extensive evidence for reducing anxiety through GABA-related pathways; all with preclinical studies of GABA-ergic action in rodent animal models, with human studies showing clinical efficacy of these extracts in people with diagnosed anxiety disorders. V.officinalis, particularly the constituent valerenic acid, has been identified as a potent allosteric modulator at GABA-A receptors. Interestingly, V.officinalis research involving dose-response effects suggest that mechanisms promote anxiolysis over sedation, with no decrements to cognitive function, even at high doses.

This article is protected by copyright. All rights reserved. 
H.lupulus, S.lateriflora, and M. officinalis also have some promising pre-clinical evidence, along with human studies of anxiolytic effects in people experiencing stress and anxiety symptoms. However, the lack of evidence showing significant benefits in people with diagnosed anxiety disorders means that the clinical utility of these particular phytomedicines has yet to be shown.

With regard to phytochemical classes of the aforementioned plant medicines; the major GABA-modulating compounds were found to be terpenoids/sesquiterpenoids and saponins classes, such as kavalactones, bilobalide, humulene, valerenic acid, along with the withanones from W.somnifera and the rosmarinic acids from Melissa officinalis. The flavonoids chrysin, apigenin ( $M$. recutita), bacalin (scutellera) are the next most evidenced for influencing GABA systems. As they have been extensively studied, flavonoids are wellknown positive modulators of GABA-A receptors, operating in the CNS by competitive benzodiazepine site binding and indirectly opening chloride channels; hyperpolarizing cell membrane and increasing the threshold for activity, thus exerting an anxiolytic effect (Johnston, 2015; Wasowski and Marder, 2012). It should be noted that despite the broad range of pre-clinical studies exploring the actions of these phytoconstituents on GABA type A receptors and their subtypes, the mechanisms of anxiolytic effect are complex, and warrant a great deal of further research in order to inform the development and evaluation of targeted phytomedicinal compounds for anxiety disorders.

One limitation of this systematic review recognised is the narrow eligibility criteria, which included only those phytomedicines with three levels evidence (in vitro, in vivo and human studies) for GABA-mediated anxiolytic effects. Although this adds strength to the review by providing focused conclusions on the anxiolytic efficacy and linked to GABA-based mechanisms of action, the strict criteria forced omission of other phytomedicines, such as Morinda citrifolia and Zizyphus jujuba, which may also potentially act to reduce anxiety via these pathways (Pawlus and Kinghorn, 2007; Gao et al., 2013), but lack sufficient investigation for inclusion in this review. 
Most notably, Magnolia officinalis has pre-clinical studies showing positive allosteric modulation of GABA-A receptors from its bioactive constituents, resulting in animal behaviours consistent with reduced anxiety (Han et al., 2011). However, the phytomedicine was excluded from the review, as there are to our knowledge no current human studies of the plant for anxiety to date, other than investigations whereby it is within a herbal combination formula. Although combination formulas of various phytomedicines have demonstrated efficacy for reducing anxiety in humans (i.e. 'Relora'; Talbott et al., 2013), the extent to which the observed anxiolytic effects are due to individual components cannot be established. Further, it is recognised that formulas which combine multiple active ingredients may be synergistically more effective; acting through independent but complimentary pathways to confer maximal effects (Bourin et al., 1997).

Future research should aim to extend beyond animal models to investigate neurobiological mechanisms of anxiolytic action in human samples with technologies such as functional magnetic resonance imaging (fMRI) and $1 \mathrm{H}$ magnetic resonance spectroscopy (1H-MRS) to examine metabolite and neurobiological changes resulting from phytomedicine intervention. Specifically, investigating GABA profile level changes in regions of the brain associated with anxiety disorders (and the related neurological dysfunction) would further elucidate the neurobiological activity of anxiolytic phytomedicines, especially regarding the interaction with GABA-ergic pathways and the resultant clinical activity. Given the existing evidence for GABA-modulating anxiolytic phytomedicines, continuing to distil the underlying operative pathways while further evaluating these compounds in rigorously designed trials (particularly in anxiety disorder samples), could ultimately lead to novel and evidence-based treatments for people with anxiety disorders, thus serving a major unmet need.

\section{Disclosures}

JS has received either presentation honoraria, travel support, clinical trial grants, book royalties, or independent consultancy payments, from Integria Healthcare \& MediHerb (a 
company sponsoring kava research), Pfizer, Scius Health, Key Pharmaceuticals, Taki Mai (a kava selling company), Bioceuticals \& Blackmores, Soho-Flordis, Healthworld, HealthEd, HealthMasters, Elsevier, Chaminade University, International Society for Affective Disorders, Complementary Medicines Australia, Terry White Chemists, ANS, Society for Medicinal Plant and Natural Product Research, Omega-3 Centre, the National Health and Medical Research Council, CR Roper Fellowship.

\section{Acknowledgements}

KS is supported by Australian Government Research Training Program (RTP) Scholarship. JF is supported by a Blackmores Institute Fellowship. JS is supported by an NHMRC fellowship (APP1125000).

\section{References}

Abuhamdah, S, Huang, L, Elliott, MS, Howes, MJ, et al. 2008. Pharmacological profile of an essential oil derived from Melissa officinalis with anti-agitation properties: focus on ligand-gated channels. J Pharm Pharmacol 60(3): 377-384.

Ahmadi, M, Khalili, H, Abbasian, L, Ghaeli, P. 2017. Effect of Valerian in Preventing Neuropsychiatric Adverse Effects of Efavirenz in HIV-Positive Patients: A Pilot Randomized, Placebo-Controlled Clinical Trial. Annals of Pharmacotherapy 51(6): 457-464.

Akbarzadeh, M, Dehghani, M, Moshfeghy, Z, Emamghoreishi, M, Tavakoli, P, Zare, N. 2015. Effect of Melissa officinalis Capsule on the Intensity of Premenstrual Syndrome Symptoms in High School Girl Students. Nursing and Midwifery Studies 4(2): e27001.

Akhondzadeh, S, Naghavi, HR, Vazirian, M, Shayeganpour, A, Rashidi, H, Khani, M. 2001. Passionflower in the treatment of generalized anxiety: a pilot double-blind randomized

controlled trial with oxazepam. J Clin Pharm Ther 26(5): 363-367.

Aman, U, Subhan, F, Shahid, M, Akbar, S, Ahmad, N, Ali, G, et al. 2016. Passiflora incarnata attenuation of neuropathic allodynia and vulvodynia apropos GABA-ergic and opioidergic antinociceptive and behavioural mechanisms. BMC Complement Altern Med 16: 77.

American Psychiatric Association. 2013. Diagnostic and Statistical Manual of Mental Disorders. (5 edn). American Psychiatric Association.: Washington, DC.

Amsterdam, JD, Li, Y, Soeller, I, Rockwell, K, Mao, JJ, Shults, J. 2009. A randomized, double-blind, placebo-controlled trial of oral Matricaria recutita (chamomile) extract therapy for generalized anxiety disorder. J Clin Psychopharmacol 29(4): 378-382.

This article is protected by copyright. All rights reserved. 
Amsterdam, JD, Shults, J, Soeller, I, Mao, JJ, Rockwell, K, Newberg, AB. 2012. Chamomile (Matricaria recutita) May Have Antidepressant Activity in Anxious Depressed Humans - An Exploratory Study. Alternative therapies in health and medicine 18(5): 44-49.

Andreatini, R, Sartori, VA, Seabra, MLV, Leite, JR. 2002. Effect of valepotriates (valerian extract) in generalized anxiety disorder: a randomized placebo-controlled pilot study. Phytotherapy Research 16(7): 650-654.

Anukunwithaya, T, Tantisira, MH, Tantisira, B, Khemawoot, P. 2016. Pharmacokinetics of a Standardized Extract of Centella asiatica ECa 233 in Rats. Planta Med.

Aoshima, H, Takeda, K, Okita, Y, Hossain, SJ, Koda, H, Kiso, Y. 2006. Effects of beer and hop on ionotropic -aminobutyric acid receptors. Journal of Agricultural and Food Chemistry(54): $2514-2519$.

Appel, K, Rose, T, Fiebich, B, Kammler, T, Hoffmann, C, Weiss, G. 2011. Modulation of the gammaaminobutyric acid (GABA) system by Passiflora incarnata L. Phytother Res 25(6): 838-843.

Aslanargun, P, Cuvas, O, Dikmen, B, Aslan, E, Yuksel, MU. 2012. Passiflora incarnata Linneaus as an anxiolytic before spinal anesthesia. J Anesth 26(1): 39-44.

Australian Bureau of Statistics, 2007. National Survey of Mental Health and Wellbeing Australian Bureau of Statistics http://www.abs.gov.au/AUSSTATS/abs@.nsf/DetailsPage/4326.02007?OpenDocument, pp. $1-100$.

Avallone, R, Zanoli, P, Corsi, L, Cannazza, G, Baraldi, M. 1996. Benzodiazepine-like compounds and GABA in flower heads of Matricaria chamomilla. Phytotherapy Research (United Kingdom).

Avallone, R, Zanoli, P, Puia, G, Kleinschnitz, M, Schreier, P, Baraldi, M. 2000. Pharmacological profile of apigenin, a flavonoid isolated from Matricaria chamomilla. Biochem Pharmacol 59(11): 1387-1394.

Awad, R, Arnason, JT, Trudeau, V, Bergeron, C, Budzinski, JW, Foster, BC, et al. 2003. Phytochemical and biological analysis of skullcap (Scutellaria lateriflora L.): a medicinal plant with anxiolytic properties. Phytomedicine 10(8): 640-649.

Awad, R, Levac, D, Cybulska, P, Merali, Z, Trudeau, VL, Arnason, JT. 2007. Effects of traditionally used anxiolytic botanicals on enzymes of the gamma-aminobutyric acid (GABA) system. Can J Physiol Pharmacol 85(9): 933-942.

Awad, R, Muhammad, A, Durst, T, Trudeau, VL, Arnason, JT. 2009. Bioassay-guided fractionation of lemon balm (Melissa officinalis L.) using an in vitro measure of GABA transaminase activity. Phytother Res 23(8): 1075-1081.

Baldwin, D, Ajel, K, Garner, M. 2010. Pharmacological treatment of generalized anxiety disorder. Curr Top Behav Neurosci(2): 453 - 467.

Baxter, AJ, Scott, KM, Vos, T, Whiteford, HA. 2013. Global prevalence of anxiety disorders: a systematic review and meta-regression. Psychological medicine 43(5): 897-910.

Becker, A, Felgentreff, F, Schroder, H, Meier, B, Brattstrom, A. 2014. The anxiolytic effects of a Valerian extract is based on valerenic acid. BMC Complement Altern Med 14: 267.

Benke, D, Barberis, A, Kopp, S, Altmann, KH, Schubiger, M, Vogt, KE, et al. 2009. GABA A receptors as in vivo substrate for the anxiolytic action of valerenic acid, a major constituent of valerian root extracts. Neuropharmacology 56(1): 174-181.

Bhattacharya, SK, Bhattacharya, A, Sairam, K, Ghosal, S. 2000. Anxiolytic-antidepressant activity of Withania somnifera glycowithanolides: an experimental study. Phytomedicine 7(6): 463-469.

This article is protected by copyright. All rights reserved. 
Blumenthal, M. 2009. Systematic reviews and meta-analyses support the efficacy of numerous popular herbs and phytomedicines. Alternative therapies in health and medicine 15(2): 1415.

Boonstra, E, de Kleijn, R, Colzato, LS, Alkemade, A, Forstmann, BU, Nieuwenhuis, S. 2015. Neurotransmitters as food supplements: the effects of GABA on brain and behavior. Frontiers in psychology 6: 1520.

Bourin, M, Bougerol, T, Guitton, B, Broutin, E. 1997. A combination of plant extracts in the treatment of outpatients with adjustment disorder with anxious mood: controlled study versus placebo. Fundam Clin Pharmacol 11(2): 127-132.

Bradwejn, J, Zhou, Y, Koszycki, D, Shlik, J. 2000. A double-blind, placebo-controlled study on the effects of Gotu Kola (Centella asiatica) on acoustic startle response in healthy subjects. J Clin Psychopharmacol 20(6): 680-684.

Brayfield, A. 2014. Martindale: The Complete Drug Reference (38 edn). Pharmaceutical Press: London.

Brinkhaus, B, Lindner, M, Schuppan, D, Hahn, EG. 2000. Chemical, pharmacological and clinical profile of the East Asian medical plant Centella asiatica. Phytomedicine 7(5): 427-448.

British Herbal Medicine Association. 1996. British Herbal Pharmacopoeia. British Herbal Medicine Association Bristol, UK.

Brock, C, Whitehouse, J, Tewfik, I, Towell, T. 2014. American Skullcap (Scutellaria lateriflora): a randomised, double-blind placebo-controlled crossover study of its effects on mood in healthy volunteers. Phytother Res 28(5): 692-698.

Bruce, SE, Yonkers, KA, Otto, MW, Eisen, JL, Weisberg, RB, Pagano, M, et al. 2005. Influence of Psychiatric Comorbidity on Recovery and Recurrence in Generalized Anxiety Disorder, Social Phobia, and Panic Disorder: A 12-Year Prospective Study. The American Journal of Psychiatry 162(6): 1179-1187.

Can, OD, Demir, U, Kiyan, HT, Demirci, B. 2012. Psychopharmacological profile of Chamomile (Matricaria recutita L.) essential oil in mice. Phytomedicine 19(3-4): 306-310.

Candelario, M, Cuellar, E, Reyes-Ruiz, JM, Darabedian, N, Feimeng, Z, Miledi, R, et al. 2015. Direct evidence for GABAergic activity of Withania somnifera on mammalian ionotropic GABAA and GABArho receptors. J Ethnopharmacol 171: 264-272.

Cases, J, Ibarra, A, Feuillere, N, Roller, M, Sukkar, SG. 2011. Pilot trial of Melissa officinalis L. leaf extract in the treatment of volunteers suffering from mild-to-moderate anxiety disorders and sleep disturbances. Med J Nutrition Metab 4(3): 211-218.

Ceremuga, TE, Johnson, LA, Adams-Henderson, JM, McCall, S, Johnson, D. 2013. Investigation of the anxiolytic effects of xanthohumol, a component of humulus lupulus (Hops), in the male Sprague-Dawley rat. AANA J 81(3): 193-198.

Ceremuga, TE, Valdivieso, D, Kenner, C, Lucia, A, Lathrop, K, Stailey, O, et al. 2015. Evaluation of the anxiolytic and antidepressant effects of asiatic acid, a compound from Gotu kola or Centella asiatica, in the male Sprague Dawley rat. AANA J 83(2): 91-98.

Chatterjee, TK, Chakraborty, A, Pathak, M, Sengupta, GC. 1992. Effects of plant extract Centella asiatica (Linn.) on cold restraint stress ulcer in rats. Indian J Exp Biol 30(10): 889-891.

Choudhary, D, Bhattacharyya, S, Joshi, K. 2017. Body weight management in adults under chronic stress through treatment with Ashwagandha root extract: A double-blind, randomized, placebo-controlled trial. Journal of Evidence-Based Complementary \& Alternative Medicine 22(1): 96-106.

This article is protected by copyright. All rights reserved. 
Chua, HC, Christensen, ET, Hoestgaard-Jensen, K, Hartiadi, LY, Ramzan, I, Jensen, AA, et al. 2016. Kavain, the Major Constituent of the Anxiolytic Kava Extract, Potentiates GABAA Receptors: Functional Characteristics and Molecular Mechanism. PLoS One 11(6): e0157700.

Dantas, LP, de Oliveira-Ribeiro, A, de Almeida-Souza, LM, Groppo, FC. 2017. Effects of passiflora incarnata and midazolam for control of anxiety in patients undergoing dental extraction. Med Oral Patol Oral Cir Bucal 22(1): e95-e101.

Dhawan, K, Kumar, S, Sharma, A. 2001. Anxiolytic activity of aerial and underground parts of Passiflora incarnata. Fitoterapia 72(8): 922-926.

Diwan, P, Karwande, I, Singh, A. 1991. Anti-anxiety profile of maduk parni (Centella Asiatica) in animals. . Fitoterapia(63): 253 - 257.

Elsas, SM, Rossi, DJ, Raber, J, White, G, Seeley, CA, Gregory, WL, et al. 2010. Passiflora incarnata L. (Passionflower) extracts elicit GABA currents in hippocampal neurons in vitro, and show anxiogenic and anticonvulsant effects in vivo, varying with extraction method. Phytomedicine 17(12): 940-949.

Ernst, E. 2006. Herbal remedies for anxiety - a systematic review of controlled clinical trials. Phytomedicine (13): 205 - 208.

Etkin, A, Wager, TD. 2007. Functional neuroimaging of anxiety: a meta-analysis of emotional processing in PTSD, social anxiety disorder, and specific phobia. Am J Psychiatry 164(10): 1476-1488.

Fehske, CJ, Leuner, K, Muller, WE. 2009. Ginkgo biloba extract (EGb761) influences monoaminergic neurotransmission via inhibition of NE uptake, but not MAO activity after chronic treatment. Pharmacol Res 60(1): 68-73.

Franco, L, Sanchez, C, Bravo, R, Rodriguez, A, Barriga, C, Juanez, JC. 2012a. The sedative effects of hops (Humulus lupulus), a component of beer, on the activity/rest rhythm. Acta Physiol Hung 99(2): 133-139.

Franco, L, Sanchez, C, Bravo, R, Rodriguez, AB, Barriga, C, Romero, E, et al. 2012b. The sedative effect of non-alcoholic beer in healthy female nurses. PLoS One 7(7): e37290.

Galster, J, Spörl, G. 1979. Entwicklung einer Skala zur Quantifizierung transitorischer und habitueller Angstzustände. Neurologie-Psychiatrie (5): 223 - 226.

Gao, QH, Wu, CS, Wang, M. 2013. The jujube (Ziziphus jujuba Mill.) fruit: a review of current knowledge of fruit composition and health benefits. J Agric Food Chem 61(14): 3351-3363.

Garrett, KM, Basmadjian, G, Khan, IA, Schaneberg, BT, Seale, TW. 2003. Extracts of kava (Piper methysticum) induce acute anxiolytic-like behavioral changes in mice. Psychopharmacology (Berl) 170(1): 33-41.

Gleitz, J, Beile, A, Peters, T. 1995. (+/-)-Kavain inhibits veratridine-activated voltagedependent $\mathrm{Na}(+)$-channels in synaptosomes prepared from rat cerebral cortex. Neuropharmacology 34(9): 1133 - 1138.

Gohil, KJ, Patel, JA, Gajjar, AK. 2010. Pharmacological Review on Centella asiatica: A Potential Herbal Cure-all. Indian J Pharm Sci 72(5): 546-556.

Grundmann, O, Wahling, C, Staiger, C, Butterweck, V. 2009. Anxiolytic effects of a passion flower (Passiflora incarnata L.) extract in the elevated plus maze in mice. Pharmazie 64(1): 63-64.

Grundmann, O, Wang, J, McGregor, GP, Butterweck, V. 2008. Anxiolytic activity of a phytochemically characterized Passiflora incarnata extract is mediated via the GABAergic system. Planta Med 74(15): 1769-1773. 
Gutierrez, S, Ang-Lee, MK, Walker, DJ, Zacny, JP. 2004. Assessing subjective and psychomotor effects of the herbal medication valerian in healthy volunteers. Pharmacol Biochem Behav 78(1): 57 64.

Guy, We. 1976. "Clinical Global Impressions". US Department of Heath, Education, and Welfare Public Health Service Alcohol, Drug Abuse, and Mental Health Administration: Rockville, MD: USA.

Hamid, K, Ng, I, Tallapragada, VJ, Varadi, L, Hibbs, DE, Hanrahan, J, et al. 2016. An Investigation of the Differential Effects of Ursane Triterpenoids from Centella asiatica, and Their Semisynthetic Analogues, on GABAA Receptors. Chem Biol Drug Des 88(3): 386-397.

Hamilton, M. 1959. The assessment of anxiety states by rating. British Journal of Medical Psychology 32: 50 - 55.

Han, H, Jung, JK, Han, SB, Nam, SY, Oh, KW, Hong, JT. 2011. Anxiolytic-like effects of 4-Omethylhonokiol isolated from Magnolia officinalis through enhancement of GABAergic transmission and chloride influx. J Med Food 14(7-8): 724-731.

Hanrahan, JR, Chebib, M, Johnston, GAR. 2011. Flavonoid modulation of GABA(A) receptors. British Journal of Pharmacology 163(2): 234-245.

Hattesohl, M, Feistel, B, Sievers, H, Lehnfeld, R, Hegger, M, Winterhoff, H. 2008. Extracts of Valeriana officinalis L. s.l. show anxiolytic and antidepressant effects but neither sedative nor myorelaxant properties. Phytomedicine 15(1-2): 2-15.

He, XG, Lin, LZ, Lian, LZ. 1997. Electrospray high performance liquid chromatography-mass spectrometry in phytochemical analysis of kava (Piper methysticum) extract. Planta Med 63(1): 70-74.

Hoffman, EJ, Mathew, SJ. 2008. Anxiety disorders: a comprehensive review of pharmacotherapies. Mt Sinai J Med 75(3): 248-262.

Houghton, PJ. 1988. The biological activity of Valerian and related plants. J Ethnopharmacol 22(2): 121-142.

Huang, L, Abuhamdah, S, Howes, MJ, Dixon, CL, Elliot, MS, Ballard, C, et al. 2008. Pharmacological profile of essential oils derived from Lavandula angustifolia and Melissa officinalis with antiagitation properties: focus on ligand-gated channels. J Pharm Pharmacol 60(11): 1515-1522.

Huang, SH, Duke, RK, Chebib, M, Sasaki, K, Wada, K, Johnston, GA. 2003. Bilobalide, a sesquiterpene trilactone from Ginkgo biloba, is an antagonist at recombinant alpha1beta2gamma2L GABA(A) receptors. Eur J Pharmacol 464(1): 1-8.

Huang, SH, Duke, RK, Chebib, M, Sasaki, K, Wada, K, Johnston, GA. 2004. Ginkgolides, diterpene trilactones of Ginkgo biloba, as antagonists at recombinant alpha1beta2gamma2L GABAA receptors. European journal of pharmacology 494(2-3): 131-138.

Huang, SH, Lewis, TM, Lummis, SC, Thompson, AJ, Chebib, M, Johnston, GA, et al. 2012. Mixed antagonistic effects of the ginkgolides at recombinant human rho1 GABAC receptors. Neuropharmacology 63(6): 1127-1139.

Ibarra, A, Feuillere, N, Roller, M, Lesburgere, E, Beracochea, D. 2010. Effects of chronic administration of Melissa officinalis L. extract on anxiety-like reactivity and on circadian and exploratory activities in mice. Phytomedicine 17(6): 397-403.

Ivic, L, Sands, TT, Fishkin, N, Nakanishi, K, Kriegstein, AR, Stromgaard, K. 2003. Terpene trilactones from Ginkgo biloba are antagonists of cortical glycine and GABA(A) receptors. J Biol Chem 278(49): 49279-49285.

This article is protected by copyright. All rights reserved. 
James, JT, Dubery, IA. 2009. Pentacyclic triterpenoids from the medicinal herb, Centella asiatica (L.) Urban. Molecules 14(10): 3922-3941.

Jana, U, Sur, TK, Maity, LN, Debnath, PK, Bhattacharyya, D. 2010. A clinical study on the management of generalized anxiety disorder with Centella asiatica. Nepal Med Coll J 12(1): 8-11.

Johnston, G, Chebib, M, Duke, R, Fernandez, S, Hanrahan, J, Hinton, T, et al. 2009. Herbal Products and GABA Receptors. In: Encyclopedia of Neuroscience pp. 1095 - 1101.

Johnston, GA. 2005. GABA(A) receptor channel pharmacology. Curr Pharm Des 11(15): 1867-1885.

Johnston, GA. 2015. Flavonoid nutraceuticals and ionotropic receptors for the inhibitory

neurotransmitter GABA. Neurochem Int 89: 120-125.

Johnston, GA, Hanrahan, JR, Chebib, M, Duke, RK, Mewett, KN. 2006. Modulation of ionotropic GABA receptors by natural products of plant origin. Adv Pharmacol 54: 285-316.

Jussofie, A, Schmiz, A, Hiemke, C. 1994. Kavapyrone enriched extract from Piper methysticum as modulator of the GABA binding site in different regions of rat brain. Psychopharmacology (Berl). 116(4): 469- 474.

Katsiotis, S, Langezaal, C, Scheffer, J. 1989. Analysis of the Volatile Compounds from Cones of Ten Humulus lupulus Cultivars. Planta Medica 55(7): 634.

Kaur, T, Singh, H, Mishra, R, Manchanda, S, Gupta, M, Saini, V, et al. 2016. Withania somnifera as a potential anxiolytic and immunomodulatory agent in acute sleep deprived female Wistar rats. Mol Cell Biochem 427(1-2): 91 - 101.

Kaviani, N, Tavakoli, M, Tabanmehr, M, Havaei, R. 2013. The efficacy of passiflora incarnata linnaeus in reducing dental anxiety in patients undergoing periodontal treatment. Journal of dentistry (Shiraz, Iran) 14(2): 68-72.

Keefe, JR, Mao, JJ, Soeller, I, Li, QS, Amsterdam, JD. 2016. Short-term open-label chamomile (Matricaria chamomilla L.) therapy of moderate to severe generalized anxiety disorder. Phytomedicine 23(14): 1699-1705.

Kennedy, DO, Little, W, Scholey, AB. 2004. Attenuation of laboratory-induced stress in humans after acute administration of Melissa officinalis (Lemon Balm). Psychosom Med 66(4): 607-613.

Kennedy, DO, Scholey, AB, Tildesley, NT, Perry, EK, Wesnes, KA. 2002. Modulation of mood and cognitive performance following acute administration of Melissa officinalis (lemon balm). Pharmacol Biochem Behav 72(4): 953-964.

Kennedy, DO, Wake, G, Savelev, S, Tildesley, NT, Perry, EK, Wesnes, KA, et al. 2003. Modulation of mood and cognitive performance following acute administration of single doses of Melissa officinalis (Lemon balm) with human CNS nicotinic and muscarinic receptor-binding properties. Neuropsychopharmacology 28(10): 1871-1881.

Khom, S, Baburin, I, Timin, E, Hohaus, A, Trauner, G, Kopp, B, et al. 2007. Valerenic acid potentiates and inhibits $\mathrm{GABA}(\mathrm{A})$ receptors: molecular mechanism and subunit specificity. Neuropharmacology 53(1): 178-187.

Khom, S, Hintersteiner, J, Luger, D, Haider, M, Pototschnig, G, Mihovilovic, MD, et al. 2016. Analysis of beta-Subunit-dependent GABAA Receptor Modulation and Behavioral Effects of Valerenic Acid Derivatives. J Pharmacol Exp Ther 357(3): 580-590.

Kiewert, C, Kumar, V, Hildmann, O, Rueda, M, Hartmann, J, Naik, RS, et al. 2007. Role of GABAergic antagonism in the neuroprotective effects of bilobalide. Brain research 1128(1): 70-78.

Kohnen, R, Oswald, WD. 1988. The effects of valerian, propranolol, and their combination on activation, performance, and mood of healthy volunteers under social stress conditions. Pharmacopsychiatry 21(6): 447-448. 
Koltermann, A, Hartkorn, A, Koch, E, Furst, R, Vollmar, AM, Zahler, S. 2007. Ginkgo biloba extract EGb 761 increases endothelial nitric oxide production in vitro and in vivo. Cell Mol Life Sci 64(13): 1715-1722.

Krenn, L. 2002. [Passion Flower (Passiflora incarnata L.)--a reliable herbal sedative]. Wien Med Wochenschr 152(15-16): 404-406.

Kuribara, H, Weintraub, ST, Yoshihama, T, Maruyama, Y. 2003. An anxiolytic-like effect of Ginkgo biloba extract and its constituent, ginkgolide-A, in mice. J Nat Prod 66(10): 1333-1337.

Lakhan, SE, Vieira, KF. 2010. Nutritional and herbal supplements for anxiety and anxiety-related disorders: systematic review. Nutr J 9: 42.

Li, J, Wang, YH, Smillie, TJ, Khan, IA. 2012. Identification of phenolic compounds from Scutellaria lateriflora by liquid chromatography with ultraviolet photodiode array and electrospray ionization tandem mass spectrometry. J Pharm Biomed Anal 63: 120-127.

Lister, R. 1987. The use of a plus-maze to measure anxiety in the mouse. Psychopharmacology (Berl) 92(2): 180 - 185.

Liu, L, Liu, C, Wang, Y, Wang, P, Li, Y, Li, B. 2015. Herbal Medicine for Anxiety, Depression and Insomnia. Current Neuropharmacology(13): 481 - 493.

Lokanathan, Y, Omar, N, Ahmad Puzi, NN, Saim, A, Hj Idrus, R. 2016. Recent Updates in Neuroprotective and Neuroregenerative Potential of Centella asiatica. Malays J Med Sci 23(1): 4-14.

Ma, L, Wang, S, Tai, F, Yuan, G, Wu, R, Liu, X, et al. 2012. Effects of bilobalide on anxiety, spatial learning, memory and levels of hippocampal glucocorticoid receptors in male Kunming mice. Phytomedicine 20(1): 89-96.

Magura, E, Kopanitsa, M, Gleitz, J, al., e. 1997. Kava extract ingredients (+)-methysticin and (+/-)kavain inhibit voltage-operated $\mathrm{Na}(+)$-channels in rat CA1 hippocampal neurons. Neuroscience 81(2): 345 - 351.

Mahita, M, Abuhamdeh, R, Howes, M, al, e. 2014. Identification of a novel GABAA receptor channel ligand derived from Melissa officinalis and Lavandula angustifolia essential oils. European Journal Med Plants 4(7).

Mao, JJ, Xie, SX, Keefe, JR, Soeller, I, Li, QS, Amsterdam, JD. 2016. Long-term chamomile (Matricaria chamomilla L.) treatment for generalized anxiety disorder: A randomized clinical trial. Phytomedicine 23(14): 1735-1742.

Martin, EI, Ressler, KJ, Binder, E, Nemeroff, CB. 2010. The neurobiology of anxiety disorders: brain imaging, genetics, and psychoneuroendocrinology. Clin Lab Med 30(4): 865-891.

Martin, HB, McCallum, M, Stofer, WD, Eichinger, MR. 2002. Kavain attenuates vascular contractility through inhibition of calcium channels. Planta Med 68(9): 784-789.

Mathews, J, Etheridge, A, Valentine, J, Black, S, Coleman, D, Patel, P, et al. 2005. Pharmacokinetics and disposition of the kavalactone kawain: interaction with kava extract and kavalactones in vivo and in vitro. Drug Metab Dispos.(33): 1555 - 1563.

McKay, DL, Blumberg, JB. 2006. A review of the bioactivity and potential health benefits of chamomile tea (Matricaria recutita L.). Phytother Res 20(7): 519-530.

Meier, B. 1995. Passifloræ Herba: Pharmazeutische Qualitat. . Zeitschrift-fur-Phytotherapie. 1995B; 16/2: 90-99 16(2): 90 - 99.

Mills, S, Bone, K. . 2000. Principles and Practice of Phytotherapy. Churchill Livingstone: Edinburgh. 
Miroddi, M, Calapai, G, Navarra, M, Minciullo, PL, Gangemi, S. 2013. Passiflora incarnata L.: ethnopharmacology, clinical application, safety and evaluation of clinical trials. J Ethnopharmacol 150(3): 791-804.

Mishra, LC, Singh, BB, Dagenais, S. 2000. Scientific basis for the therapeutic use of Withania somnifera (ashwagandha): a review. Altern Med Rev 5(4): 334-346.

Mohler, H. 2001. Pharmacology of GABA and Glycine Neurotransmission. Springer Berlin Heidelberg.

Mori, A, Hasegawa, K, Murasaki, M, Yamaguchi, T, al., e. 1993. Clinical evaluation of Passiflamin (Passiflora extract) on neurosis - multicenter, double-blind study in comparison with mexazolam. . Rinsho Hyoka [Clinical evaluation for drugs] 21(3): 383 - 440.

Movafegh, A, Alizadeh, R, Hajimohamadi, F, Esfehani, F, Nejatfar, M. 2008. Preoperative oral Passiflora incarnata reduces anxiety in ambulatory surgery patients: a double-blind, placebocontrolled study. Anesth Analg 106(6): 1728-1732.

Muller, CE, Schumacher, B, Brattstrom, A, Abourashed, EA, Koetter, U. 2002. Interactions of valerian extracts and a fixed valerian-hop extract combination with adenosine receptors. Life Sciences(71): 1939 - 1949.

Murphy, K, Kubin, ZJ, Shepherd, JN, Ettinger, RH. 2010. Valeriana officinalis root extracts have potent anxiolytic effects in laboratory rats. Phytomedicine 17(8-9): 674-678.

Nassiri-Asl, M, Zamansoltani, F, Shariati-Rad, S. 2008. Possible role of GABAA-benzodiazepine receptor in anticonvulsant effects of Pasipay in rats. Zhong xi yi jie he xue bao = Journal of Chinese integrative medicine 6(11): 1170-1173.

$\mathrm{Ng}$, CC, Duke, RK, Hinton, T, Johnston, GAR. 2017. Effects of bilobalide, ginkgolide B and picrotoxinin on GABAA receptor modulation by structurally diverse positive modulators. European journal of pharmacology 806: 83-90.

Nuss, P. 2015. Anxiety disorders and GABA neurotransmission: a disturbance of modulation. Neuropsychiatric Disease and Treatment 11: 165-175.

Olsen, RW, Sieghart, W. 2008. International Union of Pharmacology. LXX. Subtypes of $\gamma$-aminobutyric acidA receptors: classification on the basis of subunit composition, pharmacology, and function. Update. Pharmacological reviews 60(3): 243-260.

Ortiz, JG, Nieves-Natal, J, Chavez, P. 1999. Effects of Valeriana officinalis extracts on [3H]flunitrazepam binding, synaptosomal [3H]GABA uptake, and hippocampal [3H]GABA release. Neurochem Res 24(11): 1373-1378.

Pakseresht, S, Boostani, H, Sayyah, M. 2011. Extract of valerian root (Valeriana officinalis L.) vs. placebo in treatment of obsessive-compulsive disorder: a randomized double-blind study. $J$ Complement Integr Med 8.

Pawlus, AD, Kinghorn, DA. 2007. Review of the ethnobotany, chemistry, biological activity and safety of the botanical dietary supplement Morinda citrifolia (noni). The Journal of pharmacy and pharmacology 59(12): 1587-1609.

Pittler, MH, Ernst, E. 2003. Kava extract for treating anxiety. Cochrane Database Syst Rev(1): Cd003383.

Pratte, MA, Nanavati, KB, Young, V, Morley, CP. 2014. An alternative treatment for anxiety: a systematic review of human trial results reported for the Ayurvedic herb ashwagandha (Withania somnifera). J Altern Complement Med 20(12): 901-908.

Puthenkalam, R, Hieckel, M, Simeone, X, Suwattanasophon, C, Feldbauer, RV, Ecker, GF, et al. 2016. Structural Studies of GABA(A) Receptor Binding Sites: Which Experimental Structure Tells us What? Frontiers in Molecular Neuroscience 9: 44.

This article is protected by copyright. All rights reserved. 
Raines, T, Jones, P, Moe, N, Duncan, R, McCall, S, Ceremuga, TE. 2009. Investigation of the anxiolytic effects of luteolin, a lemon balm flavonoid in the male Sprague-Dawley rat. AANA J 77(1): 33-36.

Ramachandran, PV, Shekhar, A. 2011. Welcome to 'GABAergic drugs'. Future Med Chem 3(2): 139140.

Reiss, S, Peterson, RA, Gursky, DM, McNally, RJ. 1986. Anxiety sensitivity, anxiety frequency, and the prediction of fearfulness. Behaviour Research and Therapy(24): 1 - 8.

Rex, A, Morgenstern, E, Fink, H. 2002. Anxiolytic-like effects of kava-kava in the elevated plus maze test--a comparison with diazepam. Prog Neuropsychopharmacol Biol Psychiatry 26(5): 855860.

Salah, SM, Jager, AK. 2005. Screening of traditionally used Lebanese herbs for neurological activities. J Ethnopharmacol 97(1): 145-149.

Sampath, C, Holbik, M, Krenn, L, Butterweck, V. 2011. Anxiolytic effects of fractions obtained from Passiflora incarnata L. in the elevated plus maze in mice. Phytother Res 25(6): 789-795.

Santos, MS, Ferreira, F, Cunha, AP, Carvalho, AP, Ribeiro, CF, Macedo, T. 1994. Synaptosomal GABA release as influenced by valerian root extract--involvement of the GABA carrier. Archives internationales de pharmacodynamie et de therapie 327(2): 220-231.

Sarris, J. 2007. Herbal Medicines in the Treatment of Anxiety Disorders Phytotherapy Research

Sarris, J, LaPorte, E, Schweitzer, I. 2011. Kava: a comprehensive review of efficacy, safety, and psychopharmacology. Aust N Z J Psychiatry 45(1): 27-35.

Sarris, J, McIntyre, E, Camfield, D. 2013a. Plant-Based Medicines for Anxiety Disorders Part 1

Sarris, J, McIntyre, E, Camfield, D. 2013b. Plant-Based Medicines for Anxiety Disorders, Part 2: A Review of Clinical Studies with Supporting Preclinical Evidence.

Sarris, J, Stough, C, Bousman, CA, Wahid, ZT, Murray, G, Teschke, R, et al. 2013c. Kava in the treatment of generalized anxiety disorder: a double-blind, randomized, placebo-controlled study. J Clin Psychopharmacol 33(5): 643-648.

Sasaki, K, Hatta, S, Haga, M, Ohshika, H. 1999. Effects of bilobalide on gamma-aminobutyric acid levels and glutamic acid decarboxylase in mouse brain. Eur J Pharmacol 367(2-3): 165-173.

Sasaki, K, Hatta, S, Wada, K, Ohshika, H, Haga, M. 2000. Bilobalide prevents reduction of gammaaminobutyric acid levels and glutamic acid decarboxylase activity induced by 4-0methylpyridoxine in mouse hippocampus. Life Sci 67(6): 709-715.

Savage, K, Stough, C, Byrne, G, Scholey, A, Bousman, C, Murphy, J, et al. 2015. Kava for the treatment of Generalised Anxiety Disorder (K-GAD): Study protocol for a randomised controlled trial. Trials 16: 493.

Schienle, A, Hettema, J, Caceda, R, Nemeroff, C. 2011. Neurobiology and genetics of generalised anxiety disorder. Psychiatr Ann. 41(2): 113 - 123.

Schiller, H, Forster, A, Vonhoff, C, Hegger, M, Biller, A, Winterhoff, H. 2006. Sedating effects of Humulus lupulus L. extracts. Phytomedicine 13(8): 535-541.

Scholey, A, Gibbs, A, Neale, C, Perry, N, Ossoukhova, A, Bilog, V, et al. 2014. Anti-stress effects of lemon balm-containing foods. Nutrients 6(11): 4805-4821.

Shakeri, A, Sahebkar, A, Javadi, B. 2016. Melissa officinalis L. - A review of its traditional uses, phytochemistry and pharmacology. J Ethnopharmacol 188: 204-228.

Shi, Y, Dong, J, Zhao, J, Tang, L, Zhang, J. 2014. Herbal Insomnia Medications that Target GABAergic Systems: A Review of the Psychopharmacological Evidence. Current Neuropharmacology(12): 289 - 302. 
Shinomiya, K, Inoue, T, Utsu, Y, Tokunaga, S, Masuoka, T, Ohmori, A, et al. 2005. Hypnotic activities of chamomile and passiflora extracts in sleep-disturbed rats. Biol Pharm Bull 28(5): 808-810.

Shizhen, L. 1990. Li Dongyuan's Medicinal Foods [Shiwu Bencao]. Zhongguo Yiyao Keji Chubansh: Beijing.

Singh, Y. 1992. Kava: an overview. J Ethnopharmacol. 37(1): 13 - 45.

Spielberger, C, Gorsuch, R, Lushene, R, Vagg, P, Jacobs, G. 1983. Manual for the State-Trait Anxiety Inventory. Consulting Psychologists Press: Palo Alto, CA.

Srivastava, JK, Shankar, E, Gupta, S. 2010. Chamomile: A herbal medicine of the past with bright

future. Mol Med Rep 3(6): 895-901.

Stahl, S, Moore, Be. Anxiety Disorders: A Guide for Integrating Psychopharmacology and Psychotherapy. Routledge: London.

Taiwo, AE, Leite, FB, Lucena, GM, Barros, M, Silveira, D, Silva, MV, et al. 2012. Anxiolytic and antidepressant-like effects of Melissa officinalis (lemon balm) extract in rats: Influence of administration and gender. Indian J Pharmacol 44(2): 189-192.

Talbott, SM, Talbott, JA, Pugh, M. 2013. Effect of Magnolia officinalis and Phellodendron amurense (Relora(R)) on cortisol and psychological mood state in moderately stressed subjects. J Int Soc Sports Nutr 10(1): 37.

Thomas, K, Canedo, J, Perry, PJ, Doroudgar, S, Lopes, I, Chuang, HM, et al. 2016. Effects of valerian on subjective sedation, field sobriety testing and driving simulator performance. Accid Anal Prev 92: 240-244.

Trauner, G, Khom, S, Baburin, I, Benedek, B, Hering, S, Kopp, B. 2008. Modulation of GABAA receptors by valerian extracts is related to the content of valerenic acid. Planta Med 74(1): 19-24.

Tzeng, Y, Lee, M. 2015. Neuroprotective properties of kavalactones. Neural Regeneration Research 10(6): 875-877.

Ulbricht, C, Brendler, T, Gruenwald, J, Kligler, B, Keifer, D, Abrams, TR, et al. 2005. Lemon balm (Melissa officinalis L.): an evidence-based systematic review by the Natural Standard Research Collaboration. J Herb Pharmacother 5(4): 71-114.

van Beek, TA, Montoro, P. 2009. Chemical analysis and quality control of Ginkgo biloba leaves, extracts, and phytopharmaceuticals. J Chromatogr A 1216(11): 2002-2032.

Viola, H, Wasowski, C, Levi de Stein, M, Wolfman, C, Silveira, R, Dajas, F, et al. 1995. Apigenin, a component of Matricaria recutita flowers, is a central benzodiazepine receptors-ligand with anxiolytic effects. Planta Med 61(3): 213-216.

von Zerssen, D. 1976. Klinische Selbstbeurteilungsskalen (KSb-S) aus dem Münchner Psychiatrischen Informationssystem (PSYCHIS München). Beltz: Weinheim: Beltz.

Walf, A, Frye, C. 2007. The use of the elevated plus maze as an assay of anxiety-related behavior in rodents. Nat Protoc 2(2): 322-328.

Wanasuntronwong, A, Tantisira, MH, Tantisira, B, Watanabe, H. 2012. Anxiolytic effects of standardized extract of Centella asiatica (ECa 233) after chronic immobilization stress in mice. J Ethnopharmacol 143(2): 579-585.

Wang, F, Xu, Z, Ren, L, Tsang, SY, Xue, H. 2008. GABA A receptor subtype selectivity underlying selective anxiolytic effect of baicalin. Neuropharmacology 55(7): 1231-1237.

Wasowski, C, Marder, M. 2012. Flavonoids as GABAA receptor ligands: the whole story? J Exp Pharmacol 4: 9-24.

This article is protected by copyright. All rights reserved. 
Wijeweera, P, Arnason, JT, Koszycki, D, Merali, Z. 2006. Evaluation of anxiolytic properties of Gotukola--(Centella asiatica) extracts and asiaticoside in rat behavioral models. Phytomedicine 13(9-10): 668-676.

Wittchen, HU, Jacobi, F, Rehm, J, Gustavsson, A, Svensson, M, Jonsson, B, et al. 2011. The size and burden of mental disorders and other disorders of the brain in Europe 2010. European neuropsychopharmacology : the journal of the European College of Neuropsychopharmacology 21(9): 655-679.

Woelk, H, Arnoldt, KH, Kieser, M, Hoerr, R. 2007. Ginkgo biloba special extract EGb 761 in generalized anxiety disorder and adjustment disorder with anxious mood: a randomized, double-blind, placebo-controlled trial. J Psychiatr Res 41(6): 472-480.

Wohlmuth, H, Penman, KG, Pearson, T, Lehmann, RP. 2010. Pharmacognosy and chemotypes of passionflower (Passiflora incarnata L.). Biol Pharm Bull 33(6): 1015-1018.

Wolfman, C, Viola, H, Paladini, A, Dajas, F, Medina, JH. 1994. Possible anxiolytic effects of chrysin, a central benzodiazepine receptor ligand isolated from Passiflora coerulea. Pharmacol Biochem Behav 47(1): 1-4.

Wolfson, P, Hoffmann, DL. 2003. An investigation into the efficacy of Scutellaria lateriflora in healthy volunteers. Altern Ther Health Med 9(2): 74-78.

World Health Organization, 2003. Traditional Medicine, Fact Sheet World Health Organization.

Xu, Z, Wang, F, Tsang, SY, Ho, KH, Zheng, H, Yuen, CT, et al. 2006. Anxiolytic-Like Effect of baicalin and its additivity with other anxiolytics. Planta Med 72(2): 189-192.

Yin, H, Cho, DH, Park, SJ, Han, SK. 2013. GABA-mimetic actions of Withania somnifera on substantia gelatinosa neurons of the trigeminal subnucleus caudalis in mice. Am J Chin Med 41(5): 1043-1051.

Yoo, DY, Choi, JH, Kim, W, Yoo, KY, Lee, CH, Yoon, YS, et al. 2011. Effects of Melissa officinalis L. (lemon balm) extract on neurogenesis associated with serum corticosterone and GABA in the mouse dentate gyrus. Neurochem Res 36(2): 250-257.

Zhang, Z, Lian, XY, Li, S, Stringer, JL. 2009. Characterization of chemical ingredients and anticonvulsant activity of American skullcap (Scutellaria lateriflora). Phytomedicine 16(5): 485-493.

Zick, SM, Wright, BD, Sen, A, Arnedt, JT. 2011. Preliminary examination of the efficacy and safety of a standardized chamomile extract for chronic primary insomnia: A randomized placebocontrolled pilot study. BMC Complementary and Alternative Medicine 11: 78-78.

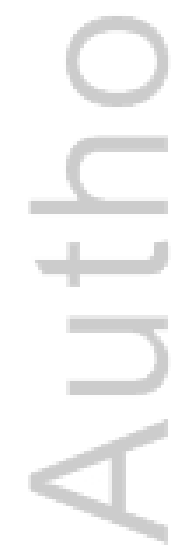

This article is protected by copyright. All rights reserved. 


\section{Appendix}

Figure 1. PRISMA flow chart showing the process of literature search and studies selection

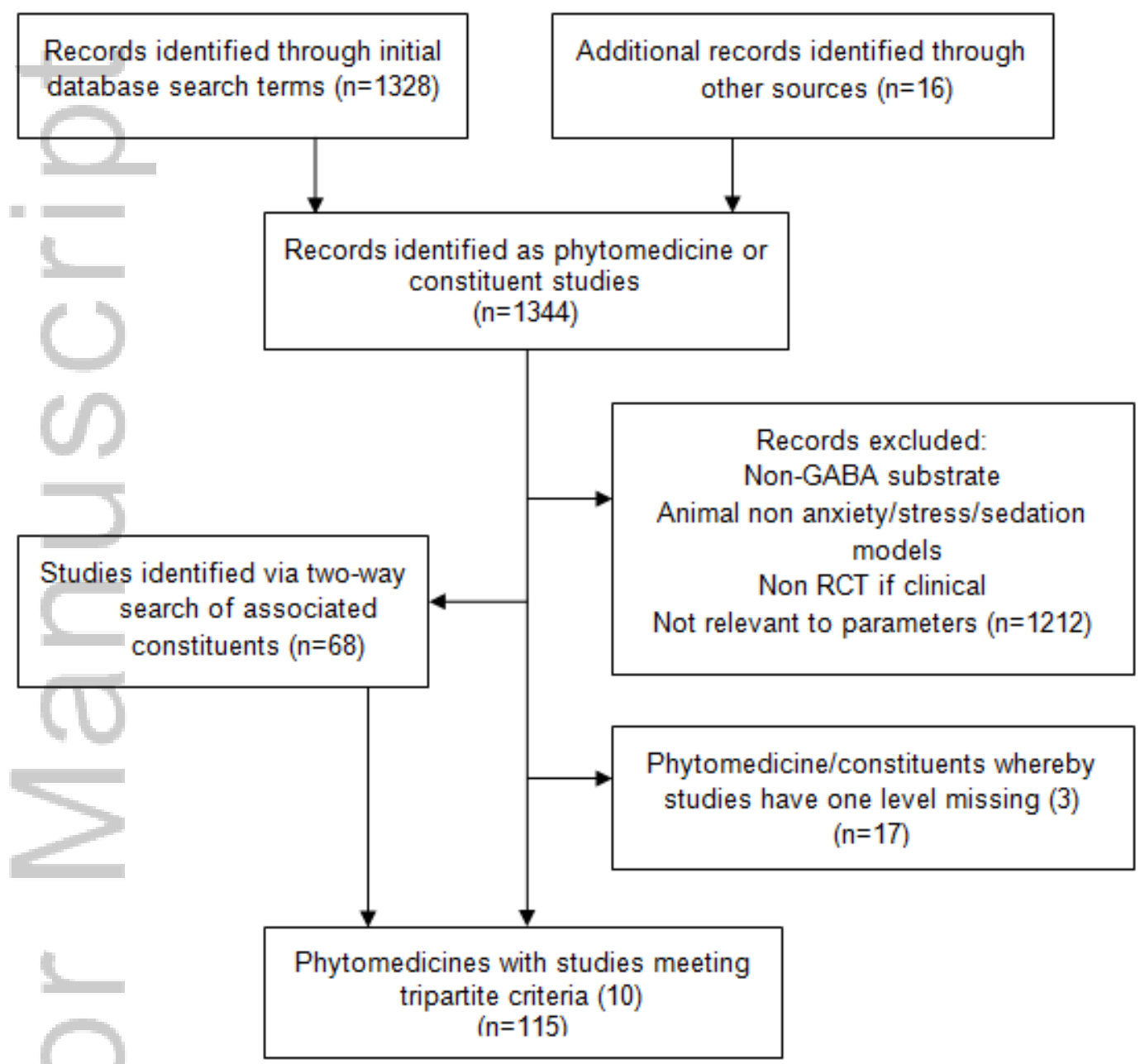

This article is protected by copyright. All rights reserved. 


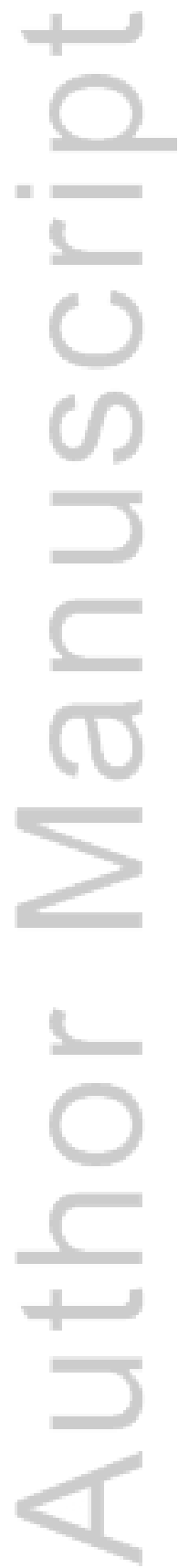

This article is protected by copyright. All rights reserved. 


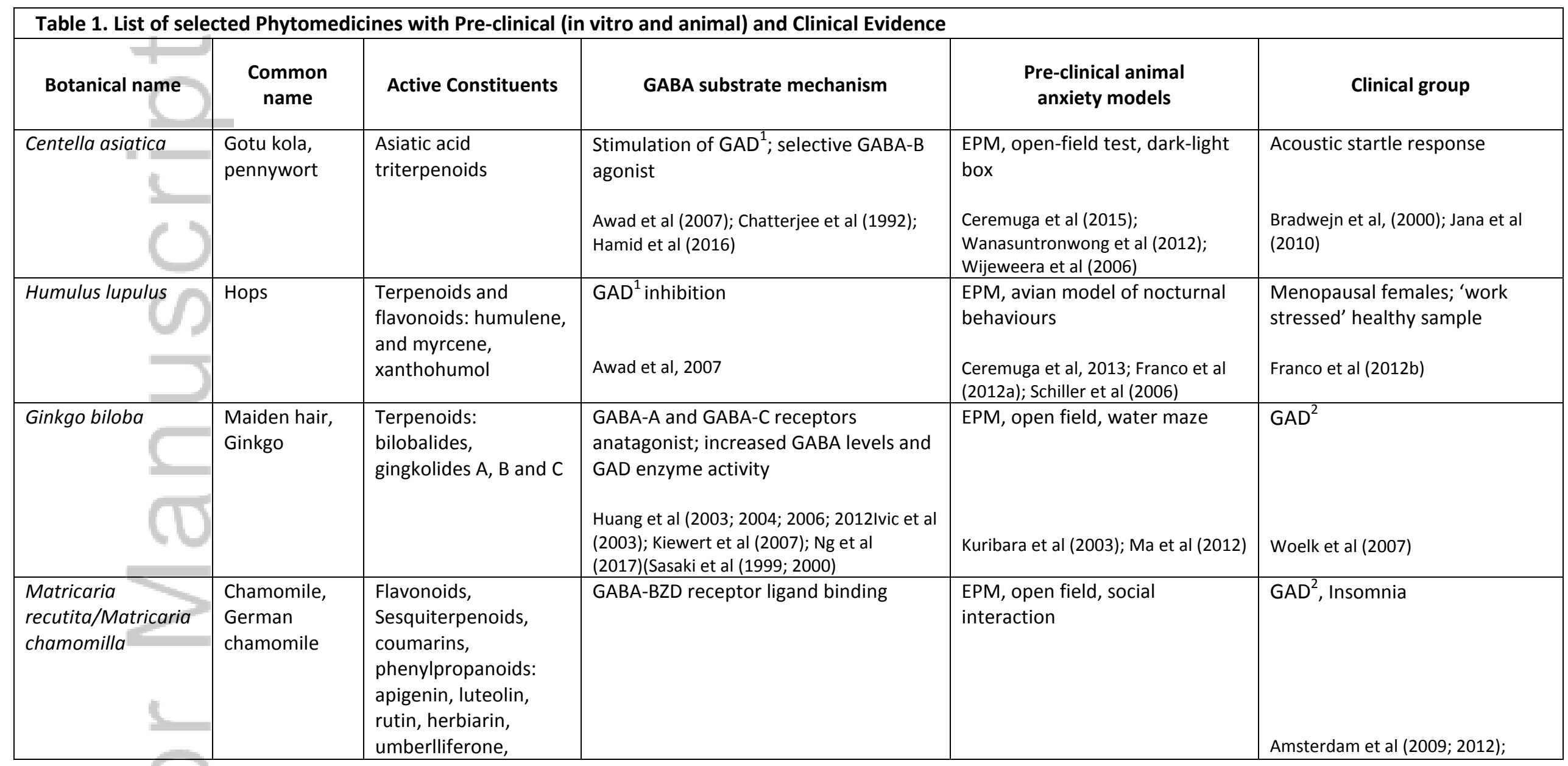

This article is protected by copyright. All rights reserved. 


\begin{tabular}{|c|c|c|c|c|c|}
\hline & $=$ & $\begin{array}{l}\text { chlorogenic and } \\
\text { caffeic acids }\end{array}$ & $\begin{array}{l}\text { Avallone et al (1996; 2000); Johnston } \\
\text { (2015); Viola et al (1995); Zanoli et al (2000) }\end{array}$ & $\begin{array}{l}\text { Can et al (2012); Shinomiya et al } \\
\text { (2005) }\end{array}$ & $\begin{array}{l}\text { Keefe et al (2016); Mao et al (2016); } \\
\text { Zick et al (2011) }\end{array}$ \\
\hline Melissa officinalis & Lemon Balm & $\begin{array}{l}\text { Flavonoids, volatile } \\
\text { oils, triterpenoids: } \\
\text { rosmarinic acid, } \\
\text { oleanolic acid, ursolic } \\
\text { acid }\end{array}$ & $\begin{array}{l}\text { GABA-T inhibition; GABA-A BDZ } \\
\text { receptor affinity; elevation of brain } \\
\text { GABA levels } \\
\text { Awad et al (2007); Awad et al (2009); } \\
\text { Abuhamdah et al (2008); Huang et al (2008); } \\
\text { Mahita et al (2014); Raines et al (2009); } \\
\text { Salah \& Jager (2005); Yoo et al (2011) }\end{array}$ & $\begin{array}{l}\text { EPM, open field rodent models } \\
\text { Ibarra et al (2010); Taiwo et al } \\
\text { (2012) }\end{array}$ & $\begin{array}{l}\text { Stress induction paradigm in } \\
\text { healthy controls; General } \\
\text { anxiety; Sleep disorders; } \\
\text { Premenstrual dysphoria } \\
\text { Akbarzadeh et al (2015); Cases et al } \\
\text { (2011); Kennedy et al (2002; 2003; } \\
\text { 2004); Scholey et al (2004; 2014) }\end{array}$ \\
\hline Passiflora incarnata & Passionflower & $\begin{array}{l}\text { Flavonoids: chrysin, b- } \\
\text { carboline } \\
\text { alkaloids }\end{array}$ & $\begin{array}{l}\text { GABA-A BDZ positive allosteric } \\
\text { modulation; GABA-A and GABA-B } \\
\text { receptor subtype affinities } \\
\text { Elsas et al (2010); Grundmann et al (2008) }\end{array}$ & $\begin{array}{l}\text { EPM, hole board, horizontal wire } \\
\text { rodent models } \\
\text { Aman et al (2016); Dawan et al } \\
\text { (2001); Elsas et al (2010); } \\
\text { Grundmann et al (2008;2009); } \\
\text { Sampath et al (2013), Wolfman et al } \\
\text { (1994) }\end{array}$ & $\begin{array}{l}\text { GAD2 ; pre-surgery } \\
\text { Anxiety } \\
\text { Akhondzadeh et al, (2001); } \\
\text { Aslanargun et al (2013), Dantas et al } \\
\text { (2017); Kaviani et al (2013); Mori et } \\
\text { al (1993); Movafegh et al (2008). }\end{array}$ \\
\hline Piper methysticum & Kava & $\begin{array}{l}\text { Kavalactones: kavain } \\
\text { and dihydrokavain }\end{array}$ & $\begin{array}{l}\text { GABA-A receptor positive modulators, } \\
\text { ligand binding at all subtypes, also NaCl, } \\
\text { Ca+ gated ion channels } \\
\text { Baxter et al (2012); Boonen \& Haberlein } \\
\text { (1998); Chua et al (2016); Davies et al } \\
\text { (1992); Gleitz et al (1995); He et al (1997); } \\
\text { Jussofie et al (1994); Magura et al (1997); } \\
\text { Martin et al (2002); Mathews et al (2005) }\end{array}$ & Garrett et al (2002); Rex et al (2003) & $\begin{array}{l}\text { GAD }^{2} \text {; phobia; social phobia; } \\
\text { nonpsychotic anxiety; stress in } \\
\text { healthy samples; menopausal } \\
\text { anxiety } \\
\text { Christensen et al (2013); La Porte et } \\
\text { al (2011); Pittler \& Ernst (2003); } \\
\text { Sarris et al (2009; 2012; 2013); } \\
\text { Singh \& Singh (2002) }\end{array}$ \\
\hline $\begin{array}{l}\text { Scutellaria } \\
\text { lateriflora }\end{array}$ & Scullcap & $\begin{array}{l}\text { Flavonoids: bacalin, } \\
\text { baicalein, scutelaterin } \\
\text { A, apigenin, oroxylin }\end{array}$ & $\begin{array}{l}\text { GABA-A receptor positive allosteric } \\
\text { modulation }\end{array}$ & EPM, open field & Healthy sample; General anxiety \\
\hline
\end{tabular}

This article is protected by copyright. All rights reserved. 


\begin{tabular}{|c|c|c|c|c|c|}
\hline & 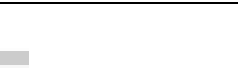 & A, wogonin & $\begin{array}{l}\text { Awad et al (2003); Wang et al (2008); Xu et } \\
\text { al (2006) }\end{array}$ & Awad et al (2003) & $\begin{array}{l}\text { Brock et al (2014); Wolfson \& } \\
\text { Hoffman, (2003) }\end{array}$ \\
\hline Valeriana spp. & $\begin{array}{l}\text { European or } \\
\text { Mexican } \\
\text { Valerian }\end{array}$ & $\begin{array}{l}\text { Sesquiterpenoids: } \\
\text { valerenic acid, } \\
\text { valepotriates, } \\
\text { alkaloids, flavonones }\end{array}$ & $\begin{array}{l}\text { GAD stimulatory effect; GABA-A } \\
\text { receptor binding, specifically GABA-A } \\
\text { chloride channel receptor complex: } \beta 2 \\
\text { or } \beta 3 \text { subunit (N265M); GABA-A } \\
\text { receptor allosteric modulation } \\
\text { Awad et al (2007); Becker et al, (2014); } \\
\text { Khom et al (2007; 2016); Ortiz et al (1999); } \\
\text { Ramharter \& Multzer (2009); Santos et al } \\
\text { (1994); Trauner et al (2008) }\end{array}$ & $\begin{array}{l}\text { EPM, light/dark choice test, } \\
\text { seizure model } \\
\text { Benke et al (2009); Kohm et al } \\
\text { (2016); Hattesohl et al (2008); } \\
\text { Murphy et al (2010) }\end{array}$ & $\begin{array}{l}\text { Children with anxiety; HIV } \\
\text { adults; healthy sample driving; } \\
\text { OCD; GAD } \\
\text { Ahmadi et al (2017); Andreatini et al } \\
\text { (2002); Gutierrez et al (2004); } \\
\text { Pakseresht et al (2011); Thomas et } \\
\text { al (2016); }\end{array}$ \\
\hline Withania somnifera & $\begin{array}{l}\text { Ashwaghanda, } \\
\text { Winter Cherry, } \\
\text { Indian Ginseng }\end{array}$ & $\begin{array}{l}\text { Glycosides alkaloids } \\
\text { and steroidal } \\
\text { triterpenoid lactones: } \\
\text { Glycowithanolides, } \\
\text { withanone, withaferin } \\
\text { A, withanolides A,D } \\
\text { and G, withanine, } \\
\text { withasamnin, } \\
\text { withanoloids }\end{array}$ & $\begin{array}{l}\text { Ionotropic GABA-A receptors; GABAp1 } \\
\text { receptor agonists }\end{array}$ & $\begin{array}{l}\text { EPM, social interaction; feeding } \\
\text { latency, unfamiliar environment }\end{array}$ & $\begin{array}{l}\mathrm{GAD}^{2} \text {; General anxiety; chronic } \\
\text { stress; bipolar disorder } \\
\text { Andrade et al (2000); Auddy et al } \\
\text { (2008); Cooly et al (2009); } \\
\text { Chandrasekhar et al (2012); } \\
\text { Chengappa et al (2013); Khyati \& } \\
\text { Ayup (2013) }\end{array}$ \\
\hline
\end{tabular}

This article is protected by copyright. All rights reserved. 


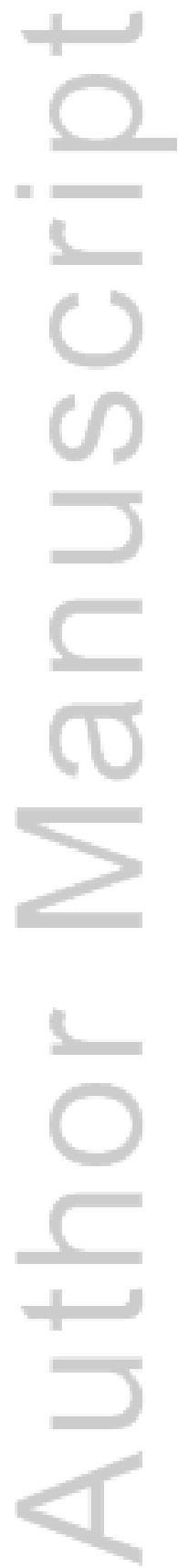

This article is protected by copyright. All rights reserved. 


\section{University Library}

\section{- M M N E R VA A gateway to Melbourne's research publications}

Minerva Access is the Institutional Repository of The University of Melbourne

Author/s:

Savage, K;Firth, J;Stough, C;Sarris, J

Title:

GABA-modulating phytomedicines for anxiety: A systematic review of preclinical and clinical evidence

Date:

2018-01-01

Citation:

Savage, K., Firth, J., Stough, C. \& Sarris, J. (2018). GABA-modulating phytomedicines for anxiety: A systematic review of preclinical and clinical evidence. PHYTOTHERAPY RESEARCH, 32 (1), pp.3-18. https://doi.org/10.1002/ptr.5940.

Persistent Link:

http://hdl.handle.net/11343/293911 